Document downloaded from:

http://hdl.handle.net/10251/140235

This paper must be cited as:

Lozano-Galant, JA.; Paya-Zaforteza, I. (2017). Analysis of Eduardo Torroja's Tempul Aqueduct an important precursor of modern cable-stayed bridges, extradosed bridges and prestressed concrete. Engineering Structures. 150:955-968.

https://doi.org/10.1016/j.engstruct.2017.07.057

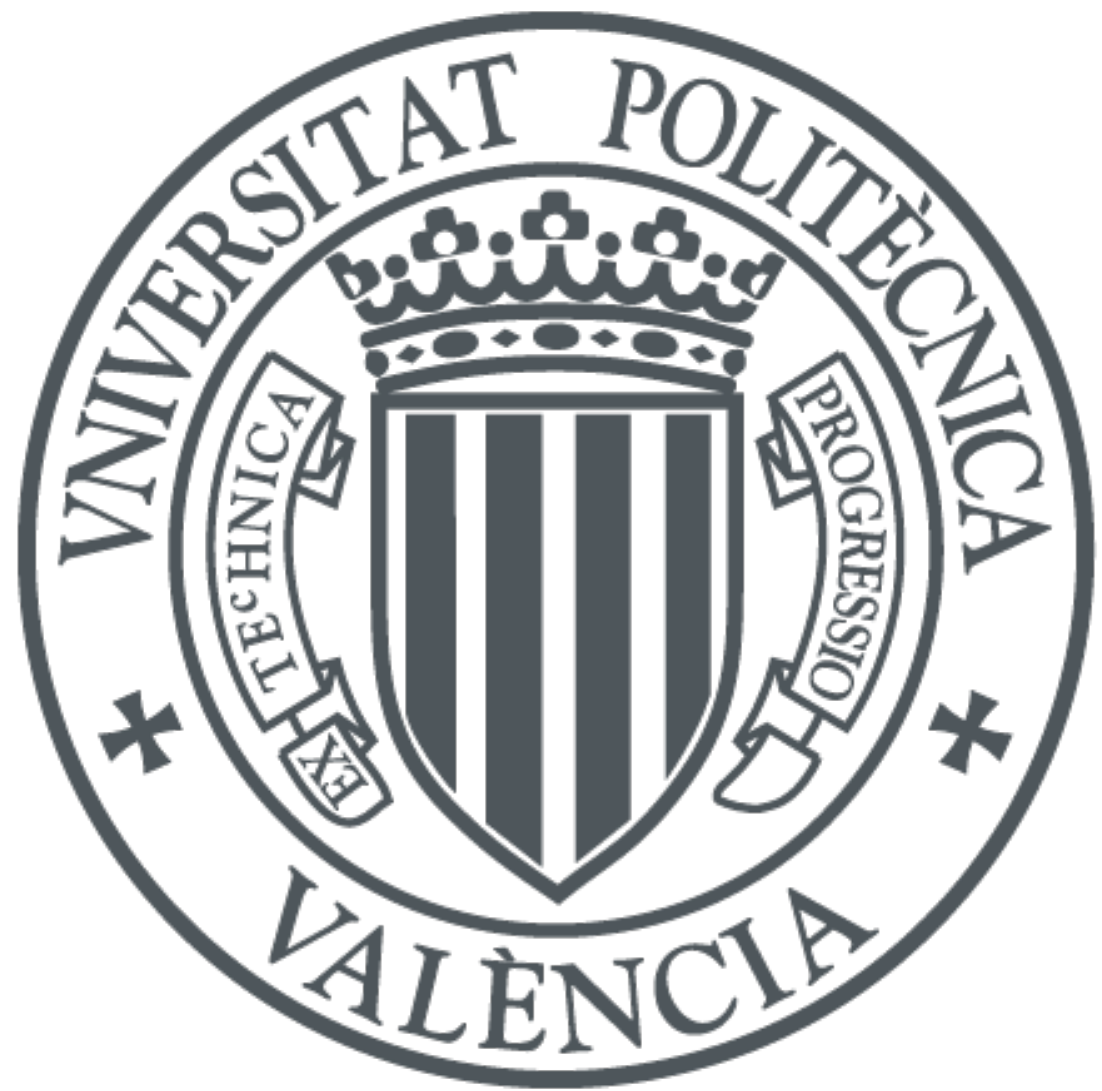

The final publication is available at

https://doi.org/10.1016/j.engstruct.2017.07.057

Copyright Elsevier

Additional Information 


\section{Please cite this paper as:}

Analysis of Eduardo Torroja'sTempul Aqueduct an important precursor of modern cable-stayed bridges, extradosed bridges and prestressed concrete Engineering Structures, 2011, 150: 955-968. DOI: 10.1016/j.engstruct.2017.07.05

\section{Highlights.}

- Eduardo Torroja's Tempul Aqueduct as an important precursor of modern cablestayed bridges.

- Critical analysis of the Tempul Aqueduct, its history and its context.

- Comparison between the results of Finite Element Models and those obtained by Torroja. 


\title{
Analysis of Eduardo Torroja'sTempul Aqueduct an important precursor of modern cable-stayed bridges, extradosed bridges and prestressed concrete
}

\author{
Jose Antonio Lozano-Galant ${ }^{1}$, Ignacio Paya-Zaforteza ${ }^{2}$ \\ ${ }^{1}$ Escuela Técnica Superior de Ingenieros de Caminos, Canales y Puertos. Universidad de \\ Castilla La Mancha. Avda. Camilo José Cela, s/n, 13071 Ciudad Real, Spain \\ ${ }^{2}$ ICITECH, Departamento de Ingeniería de la Construcción, UniversitatPolitècnica de \\ València. Camino de Vera s/n, 46022 Valencia, Spain
}

Authors e-mail addresses: Jose Antonio Lozano-Galant: joseantonio.Lozano@uclm.es

Ignacio Paya-Zaforteza: igpaza@ upv.es

\begin{abstract}
This paper describes a study of the Tempul Aqueduct, one of the first structures designed and built by Eduardo Torroja. At a time when computers did not exist, Torroja's courage and innovation were outstanding. He was in no way constrained by a lack of theoretical knowledge, inadequate materials and the contemporary doubts about cable-stayed structures. In fact, he was able to build one of the world's first prestressed concrete structures, a precursor to modern cable-stayed and extradosed bridges. This paper briefly reviews the history of the Tempul Aqueduct, gives the results of this analysis of this structure by several Finite Element Models (FEMs), and compares the FEM results to those obtained by Torroja himself. The FEM results confirm the validity of Torroja's conceptual design. The paper also contains a detailed analysis of the influence of the structural system on the behavior of the bridge and the effect of removing the live loads with the aim of providing a better understanding of the context and behavior of the Tempul aqueduct.
\end{abstract}

Keywords: Tempul aqueduct, cable-stayed bridge, extradosed bridge, prestressed concrete. 


\section{INTRODUCTION}

Cable-stayed bridges figure among the most challenging, structural efficient and aesthetic manbuilt structures. According to Strasky [1] "the beauty of these structures comes from their clear and clean structural function, which determines their architectural expression." In the last decades, the development of materials, construction techniques, simulation methods as well as the economic boom propitiated a huge increase in the construction of cable-stayed bridges worldwide. Nevertheless, these modern structures cannot be understood without the precursor cable-stayed bridges, which form the basis of this typology.

Stayed elements in tension have been widely used in structures in general and in bridges in particular since ancient times. In the first bridges, the tension elements were made of flexible materials, such as bamboo or liana [2], although the reduced lifespan of these natural materials greatly limited primitive bridges span and durability. Since the primitive stayed structures, cable-stayed bridges have evolved with time, enabling longer spans. Unlike other typologies (e.g. suspension bridges), the rapid development of cable-stayed bridges did not take place until practically the twentieth century, thanks to the works of Roebling, Gisclard, Armodin, Torroja and Dischinger. According to Podolny and Scalzy [3], this delay was attributed to a lack of technical knowledge in dealing with the difficulty of analyzing stayed-structures and the lack of suitable materials for stays. In fact, as timber or iron chains could not be prestressed, the use of these materials was discarded, as substantial deformations of the superstructure were required for the stays to remain in tension. According to Billington and Nazmy [4], the fact that the eminent engineer Navier was against cable-stayed bridges was a major issue that delayed the development of this typology. Navier's objection to cable-stayed bridges was based on facts (the collapse of structures such as the Dryburgh Bridge [3] and the Brighton Chain Pier Bridge [5]). He also had: (1) social reasons: he considered that stayed bridges did not have any economic advantage over suspension bridges and (2) symbolic reasons: he rejected the typology because the first designs came from an architect (Poyet in 1823) rather than an engineer. Billington and Nazmy [4] claim that if Navier had dedicated his talent to the development of cable-stayed bridges, this typology would probably have been developed faster.

However, despite the lack of theoretical knowledge, less than adequate materials and the experts' doubts, many cable-stayed bridges were designed up to the beginning of the 1960s. Table 1 shows the stay cable system, the span and some features of some of the most important of these bridges, among which it is easy to find several precursors of modern cable-stayed bridges (characterized by high strength steel wires and large pretension forces). Nevertheless, bridge designers and historians do not agree on which one was actually the first modern cablestayed bridge. On the one hand, a significant number of researchers (such as [3], [6-8]) state that the first modern cable-stayed bridge was the Stromsund Bridge built in Sweden in 1956. This structure was strongly influenced by the work done by Dischinger in the 1930s [4]. On the other hand, the Tempul Aqueduct, also known as the San Patricio Bridge, built in Spain in 1925 by Eduardo Torroja is considered by Virlogeux [10] and Arenas [11] as the first modern cablestayed bridge. However, Fernández-Troyano [2] is of the opinion that neither of these two structures can be considered a modern cable-stayed bridge because they were only isolated works without much impact on the subsequent bridges. 


\section{TABLE 1}

Eduardo Torroja (1899-1961) was one of the most important structural engineers of the 20th century [16]. For almost forty years, he conducted intense activity as a university professor, researcher, and consultant engineer [3, 17, 18]. He was an outstanding designer of new and innovative construction procedures and shapes in thin concrete shells (such as the Zarzuela Hippodrome Roof (1935), see [19]), the Frontón Recoletos (1935), see [20] or the CASA factory roof [21]), structures (the Fedala water storage tank (1956) or the San Nicolas Church in Gandia, see [22]) and bridges (such as Tempul (1926) or Alloz (1947)). To build such remarkable structures, Torroja developed construction technologies, built scale models and monitored his structures to check their safety, learn about their structural behavior, and improve later designs. The Tempul Aqueduct (see Fig. 1) is one of Torroja's earliest works, but already shows how his curiosity, courage, ingenuity and inventiveness solved the difficulties involved in its construction, related to the lack of scientific knowledge, adequate materials and the necessary technology. In fact, in this bridge he proposed innovative techniques for stayed cables that also introduced prestressed concrete. Tempul is also an early example of how Torroja liked to share his knowledge with the scientific and technical community, as he published the main innovations of his work as well as the results of monitoring the bridge in [23].
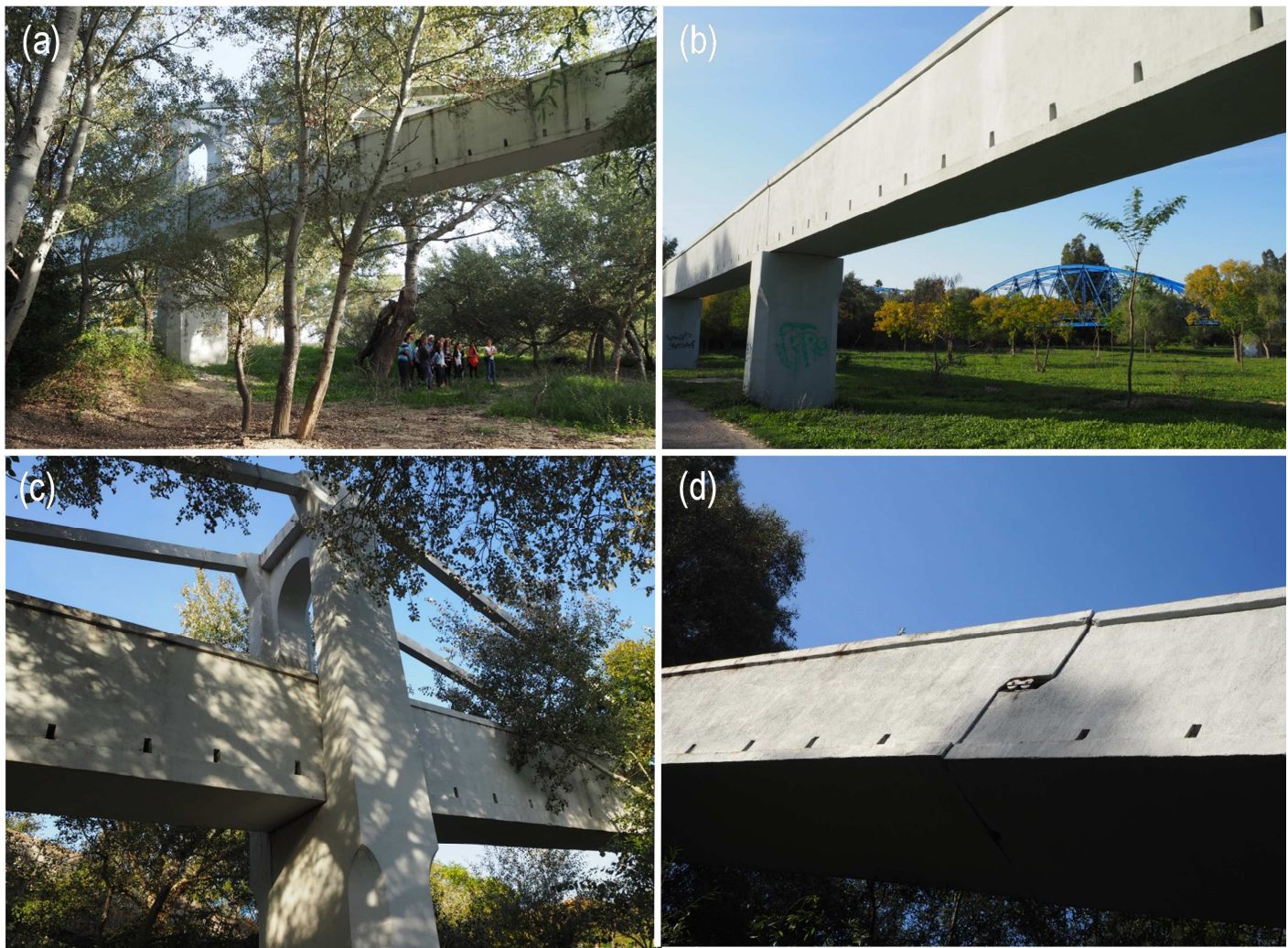

Fig 1: Current state of the Tempul Aqueduct: (a) General view. (b) Approaches. (c) Detail of the pylon. (d) Joint between the simply-supported and cantilevered spans. Pictures by Ignacio Paya-Zaforteza.

Some authors have reviewed the main characteristics and highlighted the role of the Tempul Aqueduct in the evolution of cable-stayed bridges and prestressed concrete, including J.A. Torroja-Cavanillas (E. Torroja's son) [24], also an eminent structural engineer and concrete structures professor. However, Torroja-Cavanillas' study is only based on the description of the geometry and construction of the aqueduct. 
This paper analyzes the structural behavior of the Tempul Aqueduct and compares the results obtained with Torroja's calculations. Also described is the role of the Tempul Aqueduct in the development of cable-stay bridges and an assessment of the bridge as a work of Structural Art. The authors hope that the study will inspire other engineers and architects and help to preserve the worth of a key example of bridge engineering. This study is a follow-up to previous research on Torroja's designs (see e.g. [19]-[22], [25]) and those of other engineers, such as Gustav Eiffel [26], Pier L. Nervi [27], Félix Candela [28-29], Othmar Ammann [30] and Hilario Candela [31].

\section{TEMPUL AQUEDUCT. CONCEPTUAL DESIGN, CONSTRUCTION AND REHABILITATION WORKS.}

Torroja described in [23], [32]-[34] the conceptual design and construction of the Tempul Aqueduct, a bridge over the Guadalete River that carries water to the city of Jerez de la Frontera in Southern Spain. The bridge has a length of $100 \mathrm{~m}$ and is part of a $280 \mathrm{~m}$ aqueduct. The original design of the bridge included a series of five simply supported spans $20 \mathrm{~m}$ long (see Fig. 2a). Two of the bridge piers were in the river bed and required deep foundations, but the officials who had to approve the project did not like this solution because they feared that scour could cause them to collapse (in fact, the bridge was designed to replace a former bridge destroyed by a flood in 1917). Additionally, the new design had to contain as few changes as possible from the original. Torroja studied the problem and proposed the solution depicted in Fig. 2b, where stay cables substitute the piers. In this solution the stays were supported by two pylons. This innovative solution considerably increased the engineering interest of the entire aqueduct. The new design was quickly approved and then built in 1926. The structure is made of reinforced concrete and includes two back spans of $20 \mathrm{~m}$ and a main span of $60 \mathrm{~m}$, according to [32]. This main span is supported by single stays from each pylon, with the central part of the span resting on half-joints as shown in Fig. $2 b$.

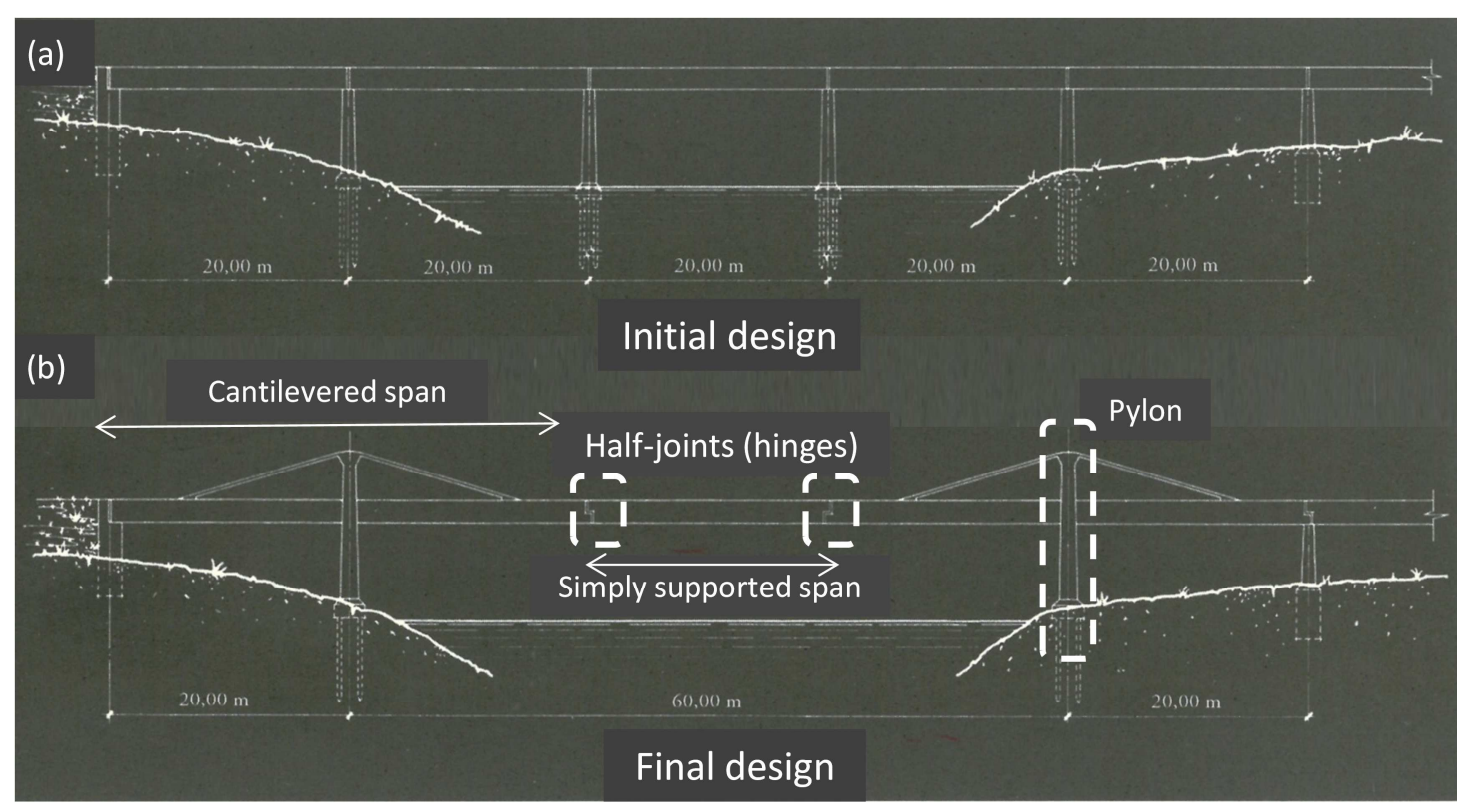

Fig 2: Tempul Aqueduct: (a) Initial proposal with piers in the riverbed and (b) Proposed design consisting of a cable-stayed bridge without piers in the riverbed. Adapted from CEHOPU - Archivo Torroja. 
Fig. 3a contains a partial elevation and a cross section of the aqueduct. The girder cross section is a hollow box $1.5 \mathrm{~m}$ high and $0.15 \mathrm{~m}$ thick that hosts a cast iron pipe with a diameter of $0.42 \mathrm{~m}$ (see Fig. 3b) that has a bulky appearance, especially on the spans away from the river. To support a total weight (including live loads) of $29.4 \mathrm{kN} / \mathrm{m}, 6$ steel bars of $30 \mathrm{~mm}$ diameter were placed in the bottom of the girder section. Every cantilever includes two balanced spans $20 \mathrm{~m}$ long suspended from a $5.8 \mathrm{~m}$ high pylon. All these elements were made of concrete with a cement dosage of $300 \mathrm{~kg} / \mathrm{m}^{3}$. To ensure the balance of the cantilevered spans, Torroja placed concrete counterweights at the extremities of the cantilevers (see Fig. 2b). The counterweight closer to the abutment weighed $420 \mathrm{kN}$ and the counterweight closer to the pier weighed $98 \mathrm{kN}$.

A major problem for Torroja was to find appropriate stays, as there was no commercial stay technology available when the aqueduct was built. According to Torroja-Cavanillas [24], the normal practice at that time was to use reinforced concrete with smooth steel bars. Nevertheless, Torroja did not trust bar splicing, as at that time welding was not sufficiently advanced, so he decided to use twisted high tensile steel cables (3 stays $63 \mathrm{~mm}$ in diameter of seven strands of 37 wires) similar to those used in harbors. The complete stays were shipped to the worksite and were placed over the saddles on top of each pylon and throughout the girder (see Fig. 3c).

Torroja was concerned about the behavior of the concrete in the stay and decided to prestress the cables by means of the following construction process: (1) first, the girder and the bottom part of the pylon (the one situated below the girder) were built using traditional formwork; (2) after one month, when the major effects of time-dependent phenomena (such as creep and shrinkage) had developed, the stay cables were prestressed. This operation was carried out by an innovative system that used two hydraulic jacks of $0.6 \mathrm{MN}$ to lift the top of the pylon. These prestressing operations made it easier to lift the girder from its formwork. (3) The formwork was removed and the live loads were then applied for 20 days to evaluate both the creep effects and the stay plastic deformation. The reported value of these deformations was $0.08 \%$ [34]. (4) The jacks were removed and, after placing some reinforcement bars, the top of the pylon (the part of the pylon above the girder) was concreted to provide long-term protection against steel corrosion and prevent excessive deflections when live loads were removed. (5) The stay cables were concreted and two joints were introduced at both stay edges to improve safety. These joints were concreted after 15 days. 

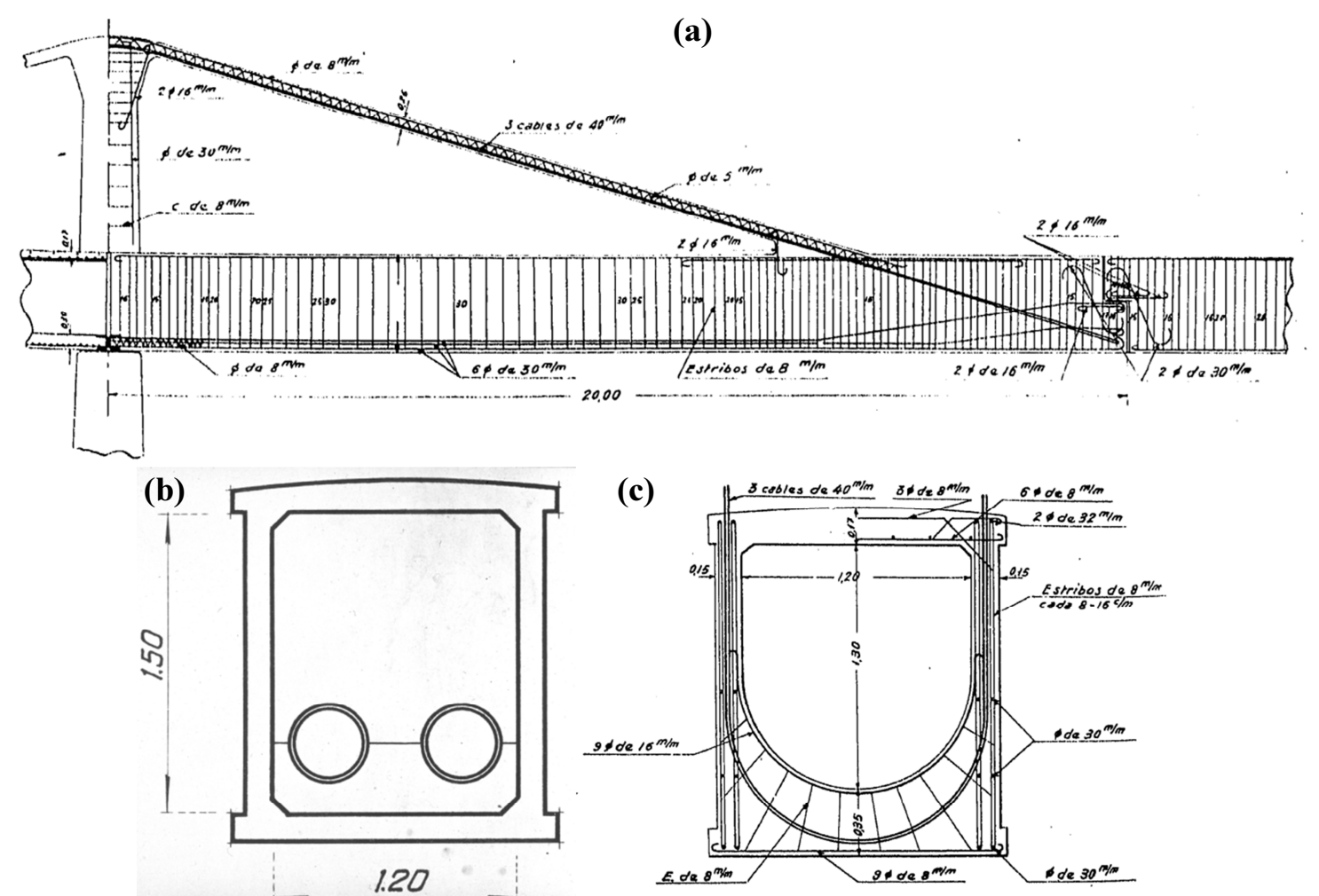

Figure3. (a) Construction drawings of the cantilever, (b)typical girder cross section with pipes (c) girder cross section at junction of steel ropes and span.Units in $\mathrm{m}$. Adapted from CEHOPU-Archivo Torroja.

The Tempul Aqueduct was given its first major renovation in 2008, 83 years after its completion. This work took 10 weeks and had a budget of $€ 477,000$. The main problems in the structure were: (1) the bad condition of the girder bearings that restrained the horizontal movements of the girder, (2) concrete cracking and loss of concrete cover due to the corrosion of the reinforcing bars, and (3) localized concrete losses in the top slab of the girder and on the top of some piers. New bearings were installed, concrete and steel sections were restored and the aqueduct was given a new protective coating [35]. Views of the deterioration, rehabilitation work and the bridge's current state can be seen in Figures 4a, 4b and 4c. As shown in Figure 4c, the aqueduct is in pristine condition today and continues to accomplish its crucial mission of providing water to Jerez de la Frontera.

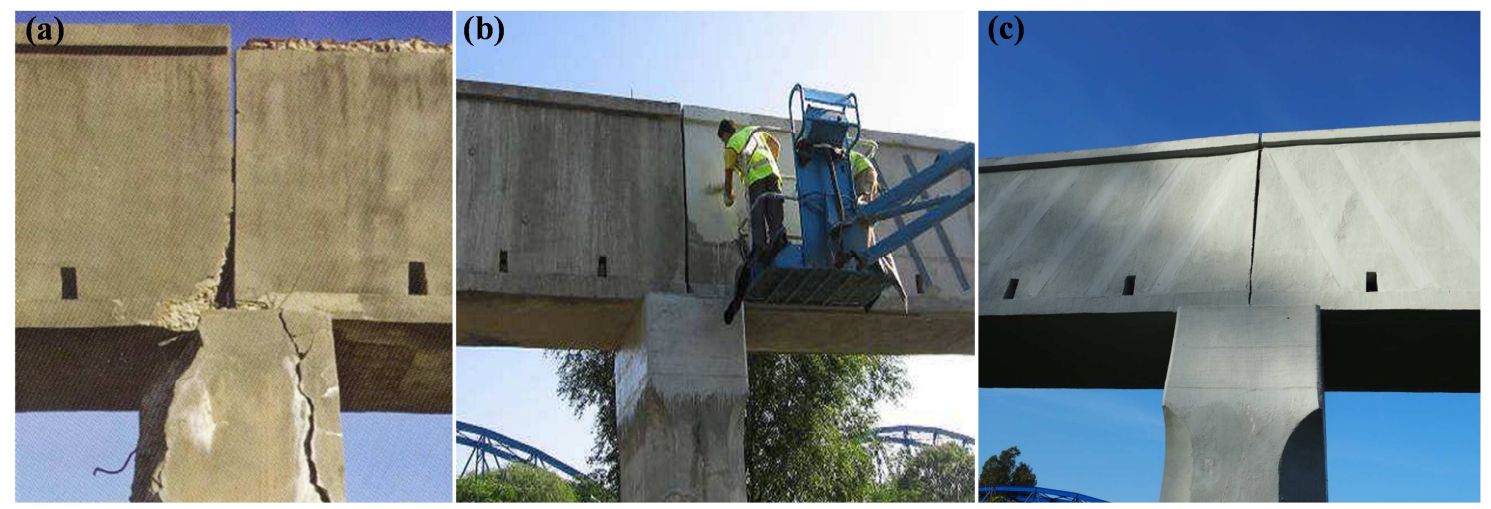

Fig 4: Tempul Aqueduct renovation works. (a) Before renovation, (b) Application of protective coating, (c) the aqueduct in October 2015, seven years later. Source: (a) and (b) COMPOSAN, (c) I. Paya-Zaforteza. 


\section{TEMPUL AQUEDUCT: THE PRECURSOR OF CABLE-STAYED AND EXTRADOSED BRIDGES.}

Whether or not the Tempul Aqueduct was the first modern cable-stayed bridge, there is no doubt that this structure is an important precursor of this typology due to the audacity of its design and technological cleverness. Before Tempul, stay systems were only used to strengthen the structure against excessive deformation. In fact, many authors, such as Roebling [13] introduced stayed systems in suspension bridges to increase bridge stiffness against wind vibration. Nevertheless, as stated by Buonopane [14], providing a substantial initial tension in the stays is of primary importance to ensure correct behavior under non-uniform loads. Aware of this fact, Roebling pioneered the idea of pre-tensioning the stays by means of the dead weight of the bridge, although this idea was not very well received by other suspension bridge designers. Alternative prestressing methods were proposed by Runyon [15], who developed a twisting device (Fig. 5a) to shorten the length of the stays, Torroja [34], who used hydraulic jacks (Fig. 5b) to increase stay length by lifting the pylon, and Freyssinet in 1928 [9], who increased stay length by means of a jack with anchorages formed by male and female cones in strands (see Fig. 5c). These devices, especially the Freyssinet jack, became authentic milestones in the evolution of cable-stayed bridges. Nowadays, the strands of the cables can be individually installed and prestressed by smaller jacks (monostrands), which speed up the prestressing operations on site. The extra strength given to each strand by these devices is calculated by means of the manufacturer's patented procedures.

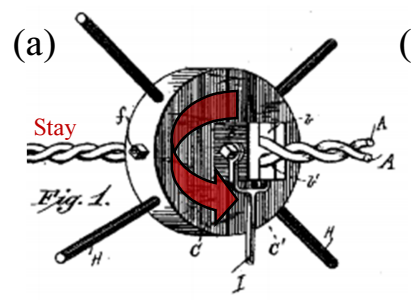

(b)

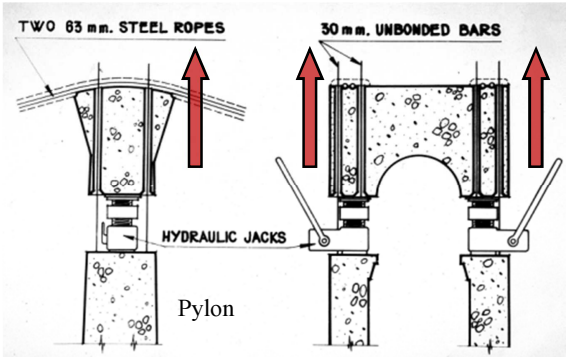

(c)

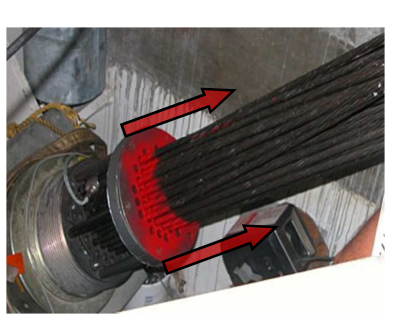

Fig. 5: Tensioning devices, (a) Twisting device by Runyon (1888). Source: Patent drawing $N^{\circ} 404934$, (b) Pylon jacks used by Torroja in Tempul. Source: [32] and (c) Jack in stays. The arrows show the movements used to prestress the stays.

In order to place Tempul Aqueduct in its historical context, Table 2 compares the main characteristics of this structure with those of its contemporary bridges (Bluff Dale Bridge (1890) [15] and the Stromsund Bridge (1956) [3]) and modern cable-stayed bridges. The parameters given in this table include:

1. Stay length: The stays are classified in terms of their length as fixed (the stay length is the same as the distance between the stay anchorages) or continuous (stay length is longer than the distance between anchorages).

2. Stay material: The materials used in the analyzed bridges are either wire strands or steel bars embedded in concrete.

3. Prestressing technology: The technology used in the analyzed structures varies from a twisting device, the pylon jack as previously described, and multistrand or monostrand stay jacks.

4. Girder stiffness: The stiffness of the analyzed girder varies from flexible to stiff. 
5. Structural behavior of the girder at mid-span: This parameter indicates if there are axial forces at the girder mid-span cross section

6. Structural analysis: The studied structures were analyzed considering different methods that vary from approximate estimates to numerical analyses with mechanical calculators and advanced computer models including detailed analysis of the construction process.

7. Structural system: The analyzed structures are either statically determinate or highly statically indeterminate.

8. Target load: A cable-stayed bridge is defined to ensure the achievement of a target structural behavior (usually that of an equivalent continuous beam) when a certain load is applied on the structure. This load, also known as target load, is traditionally achieved in service. Its value depends on the designer and might include the Self Weight of the girder, $S W$, the Superimposed Dead Load of the girder, $S D L$, and a percentage of the Live Loads, $L L$.

9. Construction process: In this section, the different stages of the construction process of the analyzed structures are summarized.

10. Durability problems: The main durability problems identified in each structure are summarized.

11. Maintenance Operations: This section describes the periodicity of maintenance operations.

Table 2: Comparison of the main properties of different cable-stayed bridges. SW=Self-Weight, SDL=Superimposed Dead Load, and LL=Live Load

\begin{tabular}{|c|c|c|c|c|}
\hline & Bluff Dale Bridge (1890) & Tempul Aqueduct (1926) & Stromsund Bridge (1956) & Modern cable-stayed bridges \\
\hline (1) Stay length & Fixed and Continuous & Continuous & Fixed & Fixed \\
\hline (2) Stay material & Parallel wire strands & Reinforced Concrete & Wirestrands & Stranded cables \\
\hline $\begin{array}{l}\text { (3) Prestressing } \\
\text { technology. }\end{array}$ & Twisting device (Fig 5a) & Jacks in pylon (Fig 5b) & Multistrand jack & Monostrand jack (Fig 5c) \\
\hline (4) Girder stiffness & Stiff & Stiff & Stiff & Flexible \\
\hline (5) Behavior at mid span: & Girder with no axial forces & Girder with no axial forces & Girder with axial forces & Girder with axial forces \\
\hline (6) Structural analysis & Simplified analyses and empirical rules & Simplified calculations & $\begin{array}{l}\text { Numerical analysis with mechanical } \\
\text { calculators }\end{array}$ & $\begin{array}{l}\text { Advanced computer models including detailed } \\
\text { construction analysis. }\end{array}$ \\
\hline (7) Structural system & Highly statically indeterminate & Statically determinate & Highly statically indeterminate & Highly statically indeterminate \\
\hline (8) Target load & SW+SDL & $\mathrm{SW}+\mathrm{SDL}+\mathrm{LL}$ & $\mathrm{SW}+\mathrm{SDL}$ & $\mathrm{SW}+\mathrm{SDL}+(0.7-0.85) \cdot \mathrm{LL}[36]$ \\
\hline (9) Construction Process & $\begin{array}{l}\text { 1- Pylon erection } \\
\text { 2- Construction of the girder on } \\
\text { cantilever using the stay cables in a } \\
\text { precambered structure } \\
\text { 3- Prestressing the stay cables to } \\
\text { achieve the desired geometry. }\end{array}$ & $\begin{array}{l}\text { 1- Construction of the girder and stay } \\
\text { placement on temporary supports. } \\
\text { 2- Increasing the pylon height. } \\
\text { 3- Placing LL. } \\
\text { 4- Cast pylon top. } \\
\text { 5- Cast stay cables. }\end{array}$ & $\begin{array}{l}\text { 1- Construction of the girder and } \\
\text { pylon on temporary supports and } \\
\text { stay-cables placement. } \\
\text { 2- Shortening the stay cables }\end{array}$ & $\begin{array}{l}\text { 1- Construction of the girder and stay placement } \\
\text { either on cantilever or temporary supports. } \\
2 \text { - Shortening the stay cables. }\end{array}$ \\
\hline (10) Durability problems & $\begin{array}{l}\text { 1- Deterioration of cable connections. } \\
\text { 2- Vegetation on superstructure. } \\
\text { 3- The bridge was closed to traffic in } \\
2015 \text { due to structural problems [37] }\end{array}$ & $\begin{array}{l}\text { 1- Girder bearings. } \\
\text { 2- Cast cover losses. } \\
3 \text { - Cast cracking. } \\
4 \text { - The structure is still in use }\end{array}$ & $\begin{array}{l}\text { No information about the durability } \\
\text { problems was found. } \\
\text { The structure is still in use. }\end{array}$ & $\begin{array}{l}\text { The most common problems refer to [40]: } \\
\text { 1- Fatigue, corrosion and anchorage of stays. } \\
\text { 2- Substructures. } \\
\text { 3- Material deterioration. }\end{array}$ \\
\hline (11) Maintenance & $\begin{array}{l}\text { The bridge lacked of maintenance until } \\
2006 \text { when the Texas Department of } \\
\text { Transportation included it into its } \\
\text { Preservation Program [38]. Then the } \\
\text { maintenance was stopped due to budget } \\
\text { problems. }\end{array}$ & $\begin{array}{l}\text { Without maintenance until } 2006 \text { when } \\
\text { the Spanish Ministry of Publish works } \\
\text { funded its first major renovation. } \\
\text { No other maintenance operations have } \\
\text { been carried. }\end{array}$ & $\begin{array}{l}\text { Maintenance carried out by the } \\
\text { company COWI annually [39]. } \\
\text { No information about the } \\
\text { maintenance activities has found. }\end{array}$ & $\begin{array}{l}\text { Principal and special inspections should be } \\
\text { carried out since the completion of the bridge. }\end{array}$ \\
\hline
\end{tabular}

The analysis of Table 2 allows the following conclusions to be drawn:

1. Stay length: Unlike modern cable-stayed bridges, the Tempul Aqueduct and the Bluff Dale Bridge include continuous stays.

2. Stay material: Unlike the rest of structures, the stay of the Tempul Aqueduct is embedded in concrete. This is the only analyzed cable-stayed bridge with a statically 
determinate structural system and is quite different to modern cable stayed bridges, which are highly statically indeterminate.

3. Prestressing technology: Each of the analyzed cable-stayed bridges used a different technology to prestress the stays. On the one hand, the Tempul Aqueduct increased the pylon height by hydraulic jacks placed inside the pylon. The approach followed by the rest of the structures is different, as they shorten the stay cable by mean of a twisting device, as in the Bluff Dale Bridge, or use hydraulic jacks. These jacks can be either multi-strand, as in Stromsund, or monostrand, as in most modern cable-stayed bridges.

4. Girder stiffness: The first steps in the development of the cable-stayed bridge typology (such as Bluff Dale Bridge, Tempul Aqueduct or the Stromsund Bridge) included a stiff girder and a small number of stay cables. On the other hand, to optimize efficiency, modern cable-stayed bridges are characterized by their flexible girders supported on multiple stay cables.

5. Structural behavior of the girder at mid span: The structural behavior of the girder of the first cable-stayed bridges (Bluff Dale Bridge and Tempul Aqueduct) included no axial forces at mid span. In the latter, the lack of these forces is explained by the fact that the girder is placed on two hinges that enable horizontal displacements. This behavior is radically different to the modern cable-stayed bridges, whose girders include tensile forces at mid-span.

6. Structural analysis: When the analyzed structures were designed different simulation tools were available, whose limitations led to simplifications and restrictions in the design, as in the case of the Tempul Aqueduct, which was calculated on paper. The simplifications included the use of girder hinges that made the structural system statically determinate. The use of these hinges, which seem an odd choice for an aqueduct, was due to Torroja's precaution, firstly because it was the first time he had designed such a structure, and secondly because this was his first large work in which the steel bars were highly prestressed. When calculators were introduced they facilitated the calculation of the Stromsund Bridge and enabled the study of the stay forces during construction, while the development of computers enabled the accurate simulation of every construction stage of the complex current cable-stayed bridges.

7. Structural system: All the analyzed structures but the Tempul Aqueduct are highly statically indeterminate. This static redundancy increases their reliability as the stress is redistributed when an element (e.g. a stay cable) fails.

8. Target load: In modern cable-stayed bridges the target load includes the SW, the SDL, and a percentage of LL. This percentage is defined by the designer and usually varies between 70 and $85 \%$ [36]. In the Tempul Aqueduct, this percentage reaches $100 \%$ because Torroja assumed that, unlike a road or a pedestrian bridge, the main LL (water) was continuously applied in service. As explained in Section 3, this consideration plays an important role in the way the stays work when the LL is removed.

9. Construction process: The construction process of the Tempul Aqueduct was radically different to those of the rest of analyzed structures. In Tempul, live loads played an important role as, unlike traditional bridges, the stays were prestressed with these loads acting on the structure. Another major issue of the construction process was the concrete of the stay cables. The need to embed the stays is explained in Section 3.

10. Durability problems: The main durability problems of the Bluff Dale Bridge refers to corrosion, to the cable connections, and excessive vegetation on the girder and pylons . Due to these problems, the bridge was closed to the traffic in 2015. No information of 
the durability problems of the Stromsund Bridge were found in the literature but most probably, as a steel structure, they would refer to material deterioration. This material deterioration can also be found in modern cable-stayed bridges together with problems in substructures and the stay cable system.

11. Maintenance: Of the three historical structures analyzed, the Stromsund Bridge is the only one inspected on a regular basis, while the last maintenance operation on the other two structures took place in 2006.

The information given in Table 2 might lead one to consider the Tempul Aqueduct as a precursor of present-day concrete extradosed bridges. This typology can be considered as an intermediate solution between a prestressed girder and a cable-stayed bridge, characterized by its short piers [41-42]. Most authors (see e.g. [10]) attribute the first extradosed bridge to Menn's Ganter Bridge built in Switzerland in 1980 (see Fig. 6a). However, some authors (see e.g. [44]) consider Mathivat as the inventor of this technique for his solution to the design competition of the Arrêt Darré Viaduct, which was never actually built. The similarity of the proportions of the Tempul Aqueduct and the Ganter Bridge can be seen in Figure 6. Figure 7 compares the geometry of Tempul (ratios of $L / d$ and $L / h$, with $d$ being the depth of the girder, $h$ the pylon height, and $L$ the main span length) to that of concrete extradosed road bridges. The comparison shows the proximity of the ratio $L / d$ of Tempul (26.7) to the ranges proposed by [41] (30.0-35.0) and [43] (30.0-45.0). Greater differences appear in the ratio $L / h$, as the value in Tempul (6.9) is located between the ranges proposed by [42-44] (10.0) and Komiya (1999) cited by [42] (3.5-5.5). Due to the similar geometry of the designs, the Tempul Aqueduct can be considered as a precursor of concrete extradosed bridges.

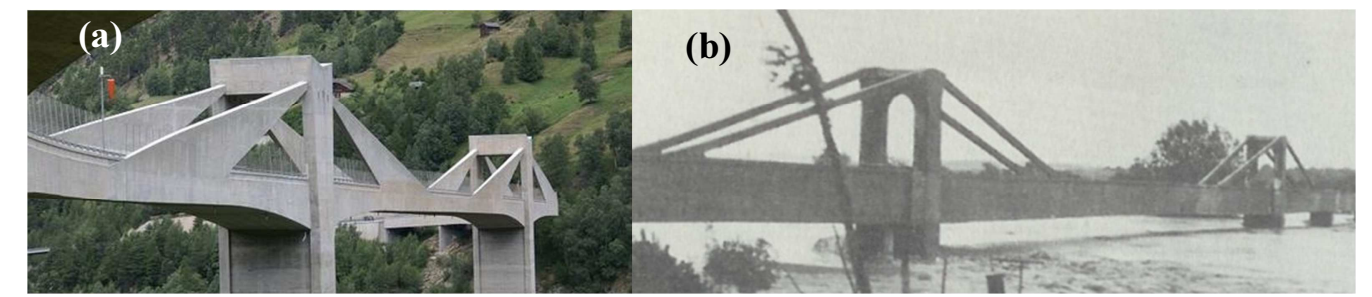

Fig. 6: Concrete Extradosed Bridges (from a morphological point of view) (a) Ganter Bridge built in 1980, (b) Tempul Aqueduct built in 1926. Sources: (a) Structurae, and (b) CEHOPU-Archivo Torroja.

(a)

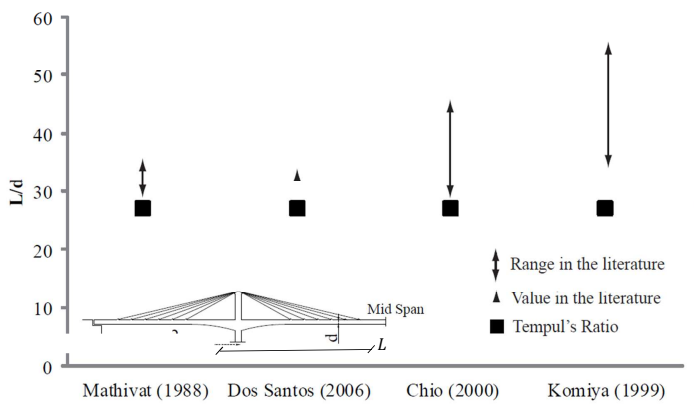

(b)

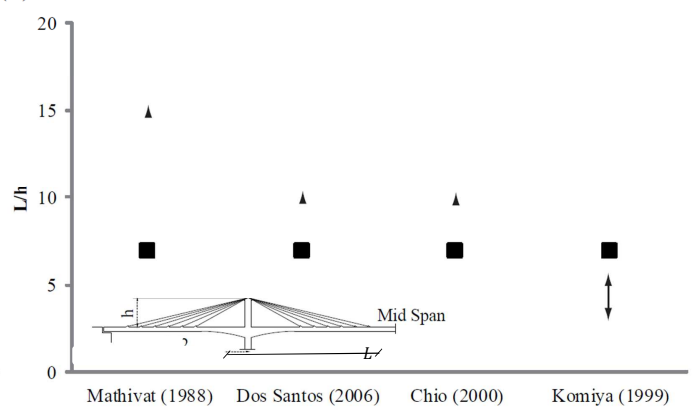

Figure 7: Comparison of the geometry of the Tempul Aqueduct with the geometry of concrete extradosed road bridges. (a) Ratio between the Length, $L$, and the depth of the girder, $d$, and (b) Ratio between L and the height of the pylon $h$. Geometric parameters of the Tempul Aqueduct are: $d=1.5 \mathrm{~m}, h=5.8 \mathrm{~m}$ and $L=40 \mathrm{~m}$. 


\section{TEMPUL AQUEDUCT AS PRECURSOR OF PRESTRESSED CONCRETE}

According to Billington [45], the principle of prestressing is considered "the single most important new concept in structural engineering during the last half of the twentieth century". This principle consisted in the introduction of an artificially created system of permanent stresses that is added to the system of stresses generated by external actions. When properly designed, the addition of these artificial stresses helps to improve the material properties. In fact, this technique opened up new possibilities that significantly extended designers' freedom. The development of prestressing is attributed to Eugene Freyssinet (1879-1962) for his construction in 1933 of prestressed concrete poles and his patents on prestressing cones. Freyssinet also highlighted the important role that high-strength steel plays in avoiding excessive prestressing losses by shrinkage and creep effects.

This section shows how stays of the Tempul Aqueduct were precursors of prestressing (see Torroja-Cavanillas in [46]). To reach this goal, the behavior of the Tempul stays is compared to traditional Reinforced Concrete (RC) and Prestressed Concrete (PC) stays in Fig. 8 and in the following paragraphs. This figure includes the stress in steel (colored in blue) and in the concrete (colored in red) for different axial forces $N$ and the arrows indicate the direction in which higher loads are introduced on site. When the concrete is not cracked in the RC stay (that is to say when the concrete tensile strength, $f_{c t k}$, is not exceeded) reinforcing steel, $\sigma_{S}$, and concrete stresses, $\sigma_{C}$, might be calculated as in Eqs (1) and (2),

$\sigma_{s}=\frac{n N}{A_{c}+n A_{s}}$

$\sigma_{c}=\frac{N}{A_{c}+n A_{s}}$

in which the term $n$ corresponds with the equivalent coefficient between steel and concrete ( $n=E_{s} / E_{c}$ ) and $A_{c}$ and $A_{s}$ are the concrete and reinforcing steel areas, respectively. The external force $N$ introduced in these equations can be expressed as follows:

$N=\sigma_{c} A_{c}+\sigma_{s} A_{s}$

Concrete cracking modifies the stresses laws given in Eqs.(1) and (2). In fact, when concrete cracks, it loses bearing capacity and the tension stress in the reinforcing steel increases as shown by the jump of the stress laws. Once concrete cracking has occurred, additional tension forces are resisted by the reinforcing steel only, according to Eq. (4):

$\sigma_{s}=\sigma_{s, c}+\frac{N-N_{c, R C}}{A_{s}}$

in which $\sigma_{S, C}$ represents the stresses in the reinforcing steel when cracking the concrete, $N$ is the total tensile force and $N_{C, R C}$ is the tensile force acting on the RC stay when cracking occurs.

The use of prestressing steel to create a PC stay is a major innovation. In a PC stay, the stay cables with an area, $A_{P}$, are prestressed with a certain stress $\sigma_{P 0}$ and an initial compression stress $\sigma_{c 0}$ is introduced in the concrete. As a result (see Fig. 8), the tensile forces that the stay is able to withstand before cracking are increased from $N_{c, R C}$ to $\mathrm{N}_{c, P C}$. The initial concrete prestressing, $\sigma_{c 0}$, can be obtained by the following equation: 
DOI: $10.1016 /$ j.engstruct.2017.07.05

$\sigma_{c 0}=\frac{\sigma_{P 0}}{n}$

The stresses in the PC stay follow Equations (6) and (7):

$\sigma_{s}=\sigma_{P 0}+\frac{n N}{A_{c}+n A_{P}}$

$\sigma_{c}=\sigma_{c 0}+\frac{N}{A_{c}+n A_{P}}$

In the RC and PC stays, increasing live loads (represented with arrows in Fig. 8) produce higher tension stresses. Nevertheless, due to its construction process, this is not the case of the Tempul stay. In this structure the stays were concreted with the entire live load acting on the bridge [23]. This construction procedure leads to the following behaviors:

1) When the aqueduct is fully loaded with water, the steel of the stays is working at a tensile tension, $\sigma_{P 0}$, and as the concrete does not carry any load, $\sigma_{c}=0$. The behavior of both materials in this construction state is represented in Fig. 8 with the index "a").

2) When the live load is totally or partially removed, the girder tends to rise, but this upwards movement is impeded by the stays and thus introduces compression forces in the stays that should add to their tension forces from the self-weight of the structure. These compression forces create compression stresses in the stay concrete and reduce the tensile stress in the steel (state "b" in Fig. 8). In the Tempul Aqueduct concrete compression stresses reached 4 $\mathrm{MPa}$. According to [34] "this compression would appear to be sufficient to cause buckling in such slender members (i.e. the stays), but in fact there is no danger in this regard since the resulting force in the stays is always a tension force". The diagrams that represent the stresses in the Tempul stays are those given in Eqs (1) and (2).

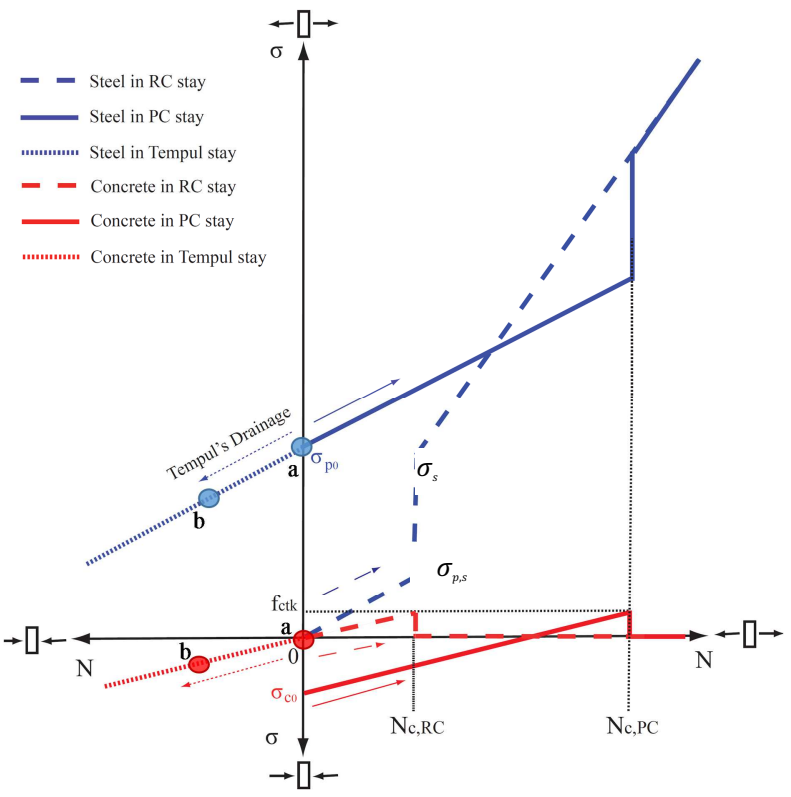

Fig. 8: Comparison of the stresses in steel and concrete in a Reinforced Concrete (RC), Prestressing Concrete (PC) and Tempul stay due to an axial load $N$.

The analysis in Fig. 8 shows how intelligent and intentional operations can be used to improve concrete performance and how the Tempul stay bridges the gap between the RC stay (whose structural behavior was known at the time of the project) and the PC stay (which would soon be 
developed by Freyssinet). In addition, the construction procedure ensured the durability of the stays by embedding them in concrete and ensuring that this concrete never cracked. Nevertheless, in a gesture that did him credit, Torroja himself always denied this role, maintaining that Freyssinet had invented prestressing and that he (Torroja) "had not deliberately sought to produce a previous and favorable tensional state, but had only solved a construction problem" [47]. Later on, in 1939 Torroja did in fact deliberately introduce prestressing in the Alloz Aqueduct.

\section{STRUCTURAL ANALYSIS OF TEMPUL AQUEDUCT}

One of the first stages in the design of a cable-stayed bridge is the definition of a target geometry and/or stress state to be achieved in service. This is traditionally known as the Objective Service Stage (OSS) (see [48-50]), in which, a given load hypothesis is counterbalanced by several resistant mechanisms that are related, to a greater or lesser extent, with the tensile forces of the stay cables. Since cable-stayed bridges are usually highly statically redundant structures, a unique solution for calculating the stay cable forces in the OSS does not exist. In this way, the prestressing forces in stays represent a design parameter that can be tailored to achieve an effective design for the bridge. However, as the number of stay cables increases, the more difficult it is to evaluate the proper set of stay cable forces in service, especially in Torroja's time when everything had to be worked out on paper. A set of assumable simplifications were therefore considered when designing the structure. In this section, these simplifications are first described together with the Torroja's results. Finite Element Models (FEMs) are then used to validate Torroja's assumptions and to check their accuracy.

\subsection{TORROJA'S CALCULATIONS}

Torroja used hand calculations based onstrenght of materials equations. The considered loads were: self-weight, $23.53 \mathrm{MN} / \mathrm{m}$, live load, $5.83 \mathrm{kN} / \mathrm{m}$, and wind load, $1.47 \mathrm{kN} / \mathrm{m}^{2}$. He minimized the material uncertainties by monitoring the built structure. For example the Young's modulus of the stay cables was calculated by measuring a dip of $0.02 \mathrm{~m}$ in the cantilever edge when it was overloaded with $5.83 \mathrm{kN} / \mathrm{m}$ [23], [34].

The documents containing his calculations include five sections: (1) Description of the main characteristics of the structure, (2) notes about inspection, pipe repair, foundations, live loads and allowable stresses, (3) structural analysis of the typical $20 \mathrm{~m}$ long span, (4) calculation of the main span (span with a total length of $60 \mathrm{~m}$ ), (5) analysis of pier foundations.

Some of other results of the structure can be found in $[23,34]$ including:

(1) The tensile stresses on the cables (ranging from 294.19 to $362.85 \mathrm{MPa}$ ).

(2) Study of the influence of the ambient temperature (an increase of $20^{\circ} \mathrm{C}$ produced a mid-span deflection of $-0.027 \mathrm{~m}$ ).

(3) Prestressing operation: The top of the pylon was raised $40 \mathrm{~cm}$ to achieve the on-site OSS. Despite its importance, Torroja left no record of the theoretical calculation of this value because the uncertainties of the materials' mechanical properties and construction procedures could result in very different theoretical values to those required in the actual structure. In fact, this value was directly tailored on site to achieve target deflections in the OSS at certain target 
points. To understand the effect of the jack, the vector of target deflections $\left\{\delta^{O S S}\right\}$ is divided into a set of passive $\left\{\delta^{P}\right\}$ and active $\left\{\delta^{A}\right\}$ vectors by applying the superposition principle as follows:

$$
\left\{\delta^{O S S}\right\}=\left\{\delta^{P}\right\}+\left\{\delta^{A}\right\}
$$

in which $\left\{\delta^{P}\right\}$ includes the passive deflections produced by permanent and live loads, and $\left\{\delta^{A}\right\}$ includes the consciously introduced active deflections by raising the pylon.

A precamber can be used as an alternative to "correct" the deflections in the passive state. According to Torroja-Cavanill in [46], in the Tempul Aqueduct the use of a precamber might have been discarded for reasons of construction and inaccuracy. For example, to get the required geometry, the deformability of the stay cables had to be correctly evaluated in advance, although this deformability was a major uncertainty. In fact, the stay elongations in the actual structure (around $1 \%$ ) were significantly greater than those expected (of the order of $0.15 \%$ ).

The hinges at the pylon-girder connection play an important role in the behavior of the structure, both in the passive and the active state. In a hinged structure no axial forces are introduced when the length of the pylon or the stays is modified because the structure is self-balanced. However, this is not the case in a hypothetically clamped girder in which the prestressing operations introduce axial forces into the stay cables.

Although no time-dependent phenomena effects were found in the calculation documents, given the overall statically determinate nature of the structure, these effects would only have a minimal effect on the structural behavior of the bridge (Torroja-Cavanillas [46])

\subsection{ANALYSIS BY FINITE ELEMENT METHOD}

This section describes a set of Finite Element Models (FEMs) built to validate Torroja's assumptions and results. These FEMs can be used to evaluate the required lifting of the jack from a theoretical point of view. To do so, the unit load method proposed by Janjic [51] is traditionally followed. According to this method, the vector of active deflections $\left\{\delta^{A}\right\}$ can be

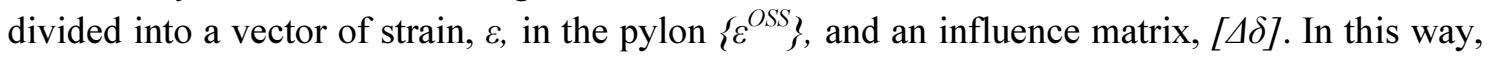
Eq. (8) can be rewritten as follows:

$\left\{\delta^{O S S}\right\}=\left\{\delta^{P}\right\}+\left\{\delta^{A}\right\}=\left\{\delta^{P}\right\}+[\Delta \delta]\left\{\varepsilon^{O S S}\right\}$

The matrix $[\Delta \delta]$ includes the deflections obtained at target locations when a unitary strain is introduced. The unknowns in Eq. (9), $\left\{\varepsilon^{O S S}\right\}$ can be directly obtained by mean of the inverse of $[\Delta \delta],[\Delta \delta]^{-1}$ as presented in the following equation:

$\left\{\varepsilon^{O S S}\right\}=[\Delta \delta]^{-1}\left(\left\{\delta^{O S S}\right\}-\left\{\delta^{P}\right\}\right)$

The same procedure is traditionally used to determine the strains, or temperature increments, in the stays of modern cable-stayed bridges. In this case, $\left\{\varepsilon^{O S S}\right\}$ represents strains in the stay cables and $[\Delta \delta]$ includes the deflections obtained at the target points when a unitary strain or temperature is introduced in each stay cable (see [52-54]).

The analyzed FEMs were chosen as simple as possible to enable the comparison with Torroja's figures worked out on paper and so the following assumptions were considered: 
(1) Both, the cable sag and the stays bending stiffness were neglected, which enabled the simulation of the stay cables with truss elements.

(2) Geometrical non-linearity was not considered, in accordance with previous work [50].

(3) The concrete cast around the stays was not included in the FEMs, since Torroja had not considered it. In any case, the main effect of this concrete is to prevent the girder from moving upwards when the live load is removed and will be the subject of future research.

(4) To enable an accurate simulation of the time-dependent phenomena, both the girder and the pylon were discretized into $1 \mathrm{~m}$ long elements in the FEMs. This led to 20 two-dimensional beam-column elements for the girder and 6 for the pylon, based on the authors' previous experience [52].

The geometry of the FEMs is summarized in Figure 9 and the structure was analyzed using SAP2000 software [55]. The main properties of the elements are summarized in Table 3.

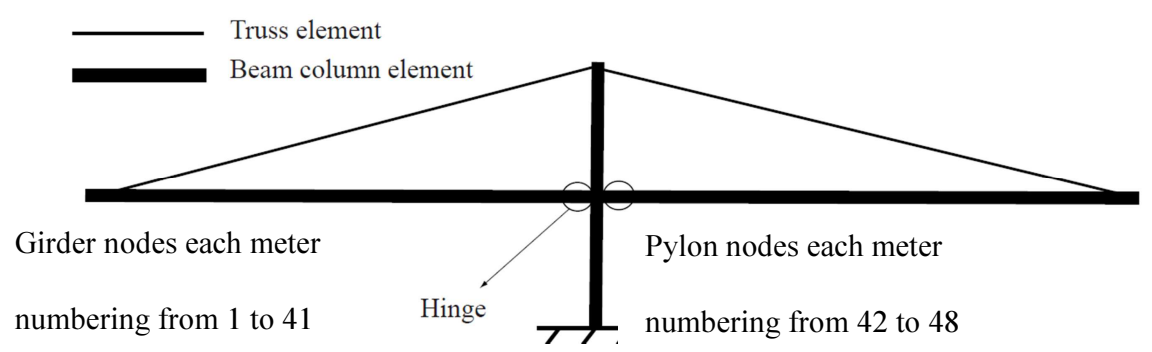

Fig 9: Simplified Finite Element Model of the Tempul Aqueduct..

Table 3: Properties and assumptions of the elements used in the FEMs.

\begin{tabular}{|c|c|c|c|c|}
\hline & Section & Area $\left[m^{2}\right]$ & Inertia $\left[\mathbf{m}^{4}\right]$ & Young's Modulus $\left[\mathrm{kN} / \mathrm{m}^{2}\right]$ \\
\hline Girder & Hollow section $1.5 \times 1.2 \times 0.15 \mathrm{~m}$ (Fig. 3a) ${ }^{(1)}$ & $1.016^{(2)}$ & $0.4796^{(2)}$ & $2.5 \times 10^{7}(3)$ \\
\hline \multirow{2}{*}{ Pylon } & Below the girder: $2.66 \mathrm{x} 0.4 \mathrm{~m}^{(1)}$ & $1.064^{(2)}$ & $0.01418^{(2)}$ & $2.5 \times 10^{7(3)}$ \\
\hline & Above the girder: 2 sections of $0.53 \times 0.4 \mathrm{~m}^{(1)}$ & $0.424^{(2)}$ & $0.0056^{(2)}$ & $2.5 \times 10^{7(3)}$ \\
\hline Stay cables ${ }^{(4)}$ & $\begin{array}{l}3 \text { strands of } 40 \mathrm{~mm}^{(1)} \\
1 \text { strands of } 63 \mathrm{~mm}^{(6)} \\
7 \text { strands with } 37 \text { wires }^{(7)}(3 \mathrm{~mm}) \\
7 \text { strands with } 37 \text { wires }^{(7)}(3.5 \mathrm{~mm}) \\
7 \text { strands with } 37 \text { wires }^{(7)}(4 \mathrm{~mm})\end{array}$ & $\begin{array}{l}0.00376^{(2)} \\
0.00312^{(6)} \\
0.00183^{(8)} \\
0.00249^{(8)} \\
0.00325^{(8)}\end{array}$ & $\begin{array}{l}0.0000^{(5)} \\
0.0000^{(5)} \\
0.0000^{(5)} \\
0.0000^{(5)} \\
0.0000^{(5)}\end{array}$ & $\begin{array}{l}2.1 \times 10^{8(6)} \\
2.1 \times 10^{8(6)} \\
2.1 \times 10^{8(6)} \\
2.1 \times 10^{8(6)} \\
2.1 \times 10^{8(6)}\end{array}$ \\
\hline $\begin{array}{l}\text { (1) From constructio } \\
\left({ }^{(2)} \text { Calculated from }\right. \\
\text { (3) No information } \\
\left({ }^{4)} \text { Contradictory sed }\right. \\
{ }^{(5)} \text { Value neglected. } \\
{ }^{(6)} \text { Defined in [34]. } \\
{ }^{(7)} \text { Partially defined } \\
{ }^{(8)} \text { Values calculatec }\end{array}$ & $\begin{array}{l}\text { rrawings. } \\
\text { ometry. } \\
\text { nd in the literature. This intermediate value has been } \\
\text { ns are found in the literature. } \\
\text { is value exceeds typical ranges of Tempul contempor } \\
\text { [34] with no information of the diameter of the wires } \\
\text { or traditional wire diameters at the construction time }\end{array}$ & $\begin{array}{l}\text { istructions (f } \\
, 3.5 \text { and } 4 \mathrm{~m}\end{array}$ & $\begin{array}{l}\text { analysis. } \\
3 \text { to } 1.8 \times 10^{8}\end{array}$ & Gimsing [7]). \\
\hline
\end{tabular}

The following points should be noted:

(1) The CEB-FIP code [56] was used to simulate the effects of the time-dependent phenomena.

(2) Torroja's on-site Young's modulus stay values $\left(2.1 \times 10^{8} \mathrm{kN} / \mathrm{m}^{2}\right.$ according to [34]) was higher than usual in stay cables at that time (which ranged between 1.3 and $1.8 \times 10^{8}$ 
$\mathrm{kN} / \mathrm{m}^{2}$, see [7]). A reduced Young's modulus percentage $\alpha$ (ranging from 0.6 to 1.0) was therefore considered in the FEMs to evaluate the effect of the Young's modulus of the actual cable.

(3) The only information Torroja provided on the concrete was its cement content (400 $\mathrm{kg} / \mathrm{m}^{3}$ at the proximities of the hinges and $300 \mathrm{~kg} / \mathrm{m}^{3}$ at the rest of girder sections), which is not enough to estimate its Young's modulus, so a set of preliminary FEMs were carried out to define this parameter. The differences between these models only referred to the Young's modulus in their girder and pylon (ranging from 1.5 to $3.5 \times 10^{7}$ $\mathrm{kN} / \mathrm{m}^{2}$ ). The results of these FEMs showed that the Young's Modulus does not play an important role in the structural behavior of the bridge, as the maximum difference in the girder bending moments and deflections is always smaller than $2 \%$, so that an intermediate Young's Modulus of $2.5 \times 10^{7} \mathrm{kN} / \mathrm{m}^{2}$ was assumed in pylon and girder sections.

(4) In Torroja's technical information, the area of the stay cables is defined in different ways. In the construction drawings, the stays are defined as 3 strands of $40 \mathrm{~mm}$ (resulting in an area of $0.00376 \mathrm{~m}^{2}$ ), while Torroja [34] states that the stay diameter is $63 \mathrm{~mm}$ (resulting in an area of $0.00312 \mathrm{~m}^{2}$ ). In the same document he also states that the stays have 7 strands of 37 wires but does not give their diameters. According to Gimsing [7], at that time wire diameters ranged between 3 and $10 \mathrm{~mm}$. The possible stay areas are thus $0.00183 \mathrm{~m}^{2}$ for $3 \mathrm{~mm}$ wires, $0.00249 \mathrm{~m}^{2}$ for $3.5 \mathrm{~mm}$ and $0.00325 \mathrm{~m}^{2}$ for $4 \mathrm{~mm}$ wires.

As the FEMs proved to be very sensitive to the stay cable area, an adequate definition of this parameter was required to mimic the results obtained on site (lifting the pylon by $40 \mathrm{~cm}$ in the active state). To find the best of the areas provided by Torroja, the OSS of different FEMs was analyzed. Each of these FEMs includes a different stay cable area $(3 \times 40 \mathrm{~mm}, 1 \times 63 \mathrm{~mm}, 7 \times 37 \times 3$ $\mathrm{mm}, 7 \times 37 \times 3.5 \mathrm{~mm}$ and $7 \times 37 \times 4 \mathrm{~mm}$ ). The required lift as calculated by Eq. (6) is summarized in Fig.10. This figure also includes the results obtained when the steel Young's modulus is reduced by $\alpha$ (ranging from 0.6 to 1.0 ). This hypothesis was assumed to evaluate the stay material uncertainty. Obviously, Fig. 10 shows that the higher the stay area and the lower the $\alpha$, the higher the jack is required to lift. The results measured by Torroja can be matched when the stays axial stiffness, $E A$, is equal to $5.53 \times 10^{5} \mathrm{kN}$. This stiffness can be simulated by different pairs of stay areas and $\alpha$ coefficient (e.g. area $3 \times 40 \mathrm{~mm}$ and $\alpha=0.6$, or area $7 \times 37 \times 3.5 \mathrm{~mm}$ and $\alpha=0.8$ ). Of these pairs the former was chosen for the FEM of the Tempul Aqueduct because this area appears in the construction drawings. The results obtained prove Torroja's assumption of the actual behavior of the materials in general and the stay cables in particular, as $\alpha$ is lower than 1. 


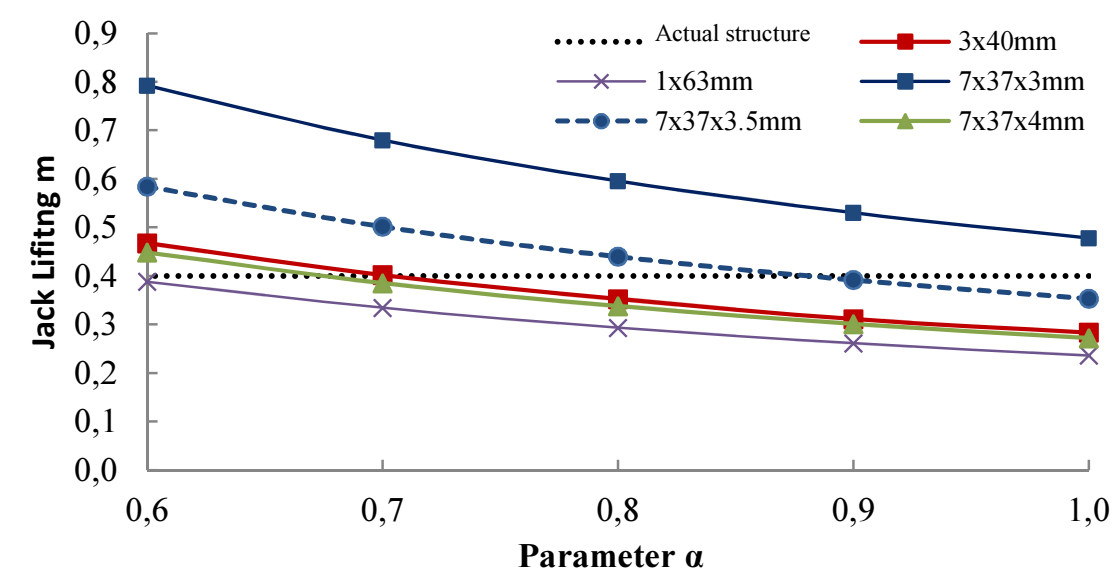

Fig 10: Comparison of the required jack lifting $(\mathrm{m})$ required to achieve the OSS in different FEMS.

At the time when the Tempul Aqueduct was designed no theoretical models were available to simulate the time-dependent phenomena (such as creep and shrinkage behavior). For that reason Torroja could not analyze these effects. A set of FEMs was thus analyzed to evaluate creep and shrinkage based on the geometry described in the preceding section, considering a notional size of $0.38,0.35$ and $0.29 \mathrm{~m}$, for the girder, the pylon below the girder and the pylon over the girder sections, respectively. However, this information could not be used to evaluate creep and shrinkage, as the value of some important parameters (such as relative humidity and the dilatation coefficient) were not known, and so these parameters were given the usual values (relative humidity $75 \%$ and dilatation coefficient $1.2 \times 10^{-5} \mathrm{C}^{\mathrm{o}^{-1}}$ ).

\subsection{FEM RESULTS}

This section gives the results of the hinged and a hypothetically clamped cantilever bridge FEMs of the Tempul Aqueduct, assuming the steel and concrete Young's modulus to be $1.47 \times 10^{8} \mathrm{kN} / \mathrm{m}^{2}$ and $2.5 \times 10^{7} \mathrm{kN} / \mathrm{m}^{2}$, respectively.

The active strains required to ensure OSS achievement were calculated by Eq. (10), neglecting the effects of time-dependent phenomena during construction. The increment of temperature required in the pylon obtained by this equation is $205.3{ }^{\circ} \mathrm{C}$. The same effect can be obtained by a uniform temperature variation of $-510.7{ }^{\circ} \mathrm{C}$ in the stay cables. This increment value is significantly higher than the strains in modern cable-stayed bridges (usually of the order of -300 ${ }^{\circ} \mathrm{C}$ [57]). In Tempul, the axial forces in the girder $(2060.1 \mathrm{kN})$ are close to those defined by Torroja in $[23,34](1863.9 \mathrm{kN})$. The differences between these two values can be attributed to the weight of the stays, which Torroja neglected.

When the pylon-girder connection is assumed as clamped, the passive deflection of the cantilever edge is reduced from -40.0 to $-8.6 \mathrm{~cm}$. This deflection can be corrected by an increment of temperature of $205.3{ }^{\circ} \mathrm{C}$ in the pylon or $-446.4{ }^{\circ} \mathrm{C}$ in the stay cables.

To ensure the correct behavior of the Tempul Aqueduct, the analysis of this structure was not limited to the OSS and other parameters (such as the deflections in the girder produced by a 20 ${ }^{\circ} \mathrm{C}$ increment of temperature in the concrete and steel materials). In this case, the dips of the cantilever edges are 17.94 and $19.08 \mathrm{~mm}$ for the steel and concrete temperature increments, which are close to the $27 \mathrm{~mm}$ measured by Torroja [23], [34]). The effect of removing the live 
load of the water was also analyzed. As the OSS defined includes this load, the target structural behavior is achieved when this load appears in the structure. Due to the nature of this load (which was applied throughout the entire service life of the structure), its effects were included in the definition of the stay cable prestressing forces, although it does not always appear in the structure (due e.g. to maintenance work). In this case, the girder tends to lift due to stay prestressing. The maximum lift obtained in the structure $(8.12 \mathrm{~cm})$ is at the cantilever edges and is only $1.49 \mathrm{~cm}$ with a clamped pylon-girder connection. To limit unfavorable lifting of the girder when the live load is removed, Torroja covered the stay cables in concrete. Buckling in this element is almost ruled out because the stay is always in tension, which was a major innovation. The deformation of the concrete stay, $\delta$, is defined as follows:

$\delta=\frac{L}{E A} \cdot F$

in which $\mathrm{L}$ is the length of the stay cable $(20.85 \mathrm{~m}), E$ is the Young's modulus, $A$ is the area $\left(0.2 \times 0.25=0.05 \mathrm{~m}^{2}\right)$, and $F$ is the compression force in the stay when the live load is removed, which in this case has a value of $230.0 \mathrm{kN}$. Once $\delta$ has been defined, this parameter can be used to estimate the length of the stressed stay cable $L$ ' as follows:

$\mathrm{L}^{\prime}=\mathrm{L}-\delta$

From the stressed length $L^{\prime}$, the vertical deformation of the edge of the cantilever can be graphically defined. To do so, a circle with $L$ ' radii is drawn from the top of the pylon. The vertical deflection at the cantilever edge is obtained by intersecting this circle with a vertical line at the cantilever edge. From this value, the deflection of the rest of the points on the girder can be linearly defined, neglecting the horizontal deflection of the girder. As the Young's modulus of the concrete was not defined in the technical documentation of the bridge, three different hypotheses were analyzed $\left(C_{l}\right.$ with $E=1.5 \times 10^{7} \mathrm{kN} / \mathrm{m}^{2}, C_{2}$ with $E=2.5 \times 10^{7} \mathrm{kN} / \mathrm{m}^{2}$ and $C_{3}$ with $E=3.5 \times 10^{7} \mathrm{kN} / \mathrm{m}^{2}$ ). Obviously, the higher the concrete Young's modulus, the lower the $\delta$ and $L$ ' and therefore the less the girder lifts. The values obtained were 2.31, 1.49 and 1.01 $\mathrm{cm}$ for $\mathrm{C}_{1}, \mathrm{C}_{2}$ and $\mathrm{C}_{3}$, respectively. From these values the rest of the deflections in the girder can be linearly obtained. The lifted girder geometry for each of these cases is shown in Fig. 11, together with that obtained with no concrete around the stay cable in the hinged and clamped structure.

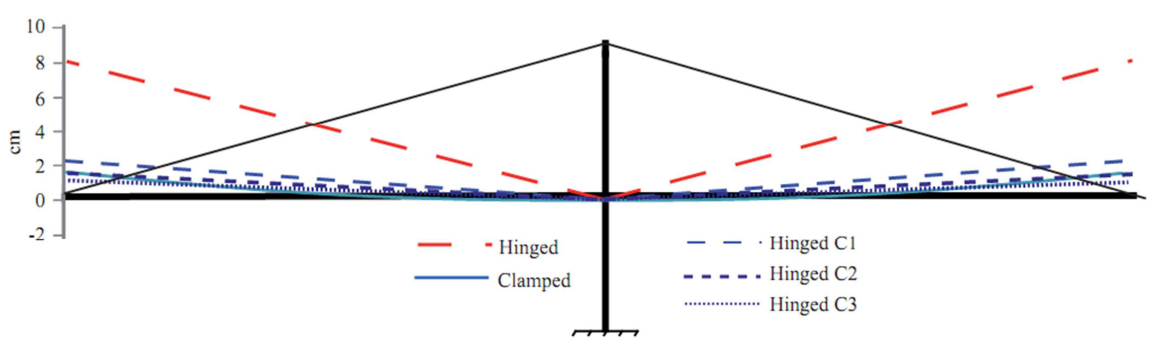

Fig. 11: Vertical deflections when the live loads are removed in structures without concrete around stays (hinged and clamped) and with concrete around stays $\left(C_{1}, C_{2}\right.$ and $\left.C_{3}\right)$.

\section{A CRITICAL ANALYSIS OF THE TEMPUL AQUEDUCT.}

The previous sections have highlighted the great value of the Tempul Aqueduct as a precursor to cable-stayed bridges, extradosed bridges and prestressed concrete, however the Tempul aqueduct is also worthy of note for its other qualities. 
First of all, its outstanding conceptual design and construction: (1) the project was built without any cost increases and has survived major floods in the course of its existence (see Fig. 6b), and (b) it was in service for nearly 80 years before undergoing renovation.

Secondly, Tempul reminds us of the importance of simplified pencil and paper calculations; Torroja managed to complete the entire structural analysis in only seven pages.

Thirdly, the structure is also the results of the engineer's courage, humility and high standards. When looking back in his 1958 book "Philosophy of Structures" [32], Torroja wrote that in order to avoid deformation of the different elements he put hinges in the bridge, that "would have been unnecessary in a continuous beam structure". And then added "It is true that today I might not have this fear; but I had it then, because that was the first time it was done and, in a way, the first work in which post-tensioning had been used on a large scale". Torroja's courage in this design is remarkable if we consider his age: his signature on the Tempul design project is dated May $25^{\text {th }}, 1925$, so that he produced a masterpiece when he was only 25 years old on his first job for the Hidrocivil Construction Company.

Finally, the structure aesthetics is another point that deserves special attention. The approach spans could be considered as bulky because of their depth as compared to the height of the piers (see Fig. 1b). However, this depth was not Torroja's choice, but a project constraint. The interior of the girder had to be able to be visible for inspection. Other notable aesthetic details include the treatment of the vertical corners of piers and pylon (see Fig. $1 \mathrm{~b}$ and1c, respectively) or the arch in the beam connecting the top part of the pylon. (Fig. 12). According to TorrojaCavanillas [24], this element highlights the relationship between the aqueduct and Andalusian tradition by including an arch instead of simply a straight beam. The present authors consider that the elegance of the structure lies in something more subtle than its visual appearance, which is its completeness: as Fernández-Ordóñez and Navarro-Vera [18] have pointed out, the aqueduct is "a complete fusion between function, structure and construction process that is revealed in a new form".

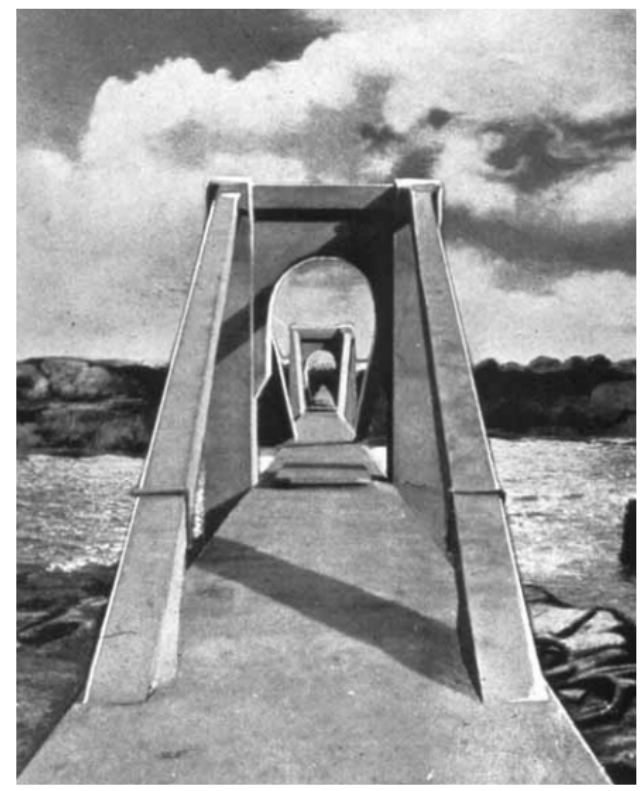


Fig. 12:Arch pylon of the San Patricio Bridge

(Tempul Aqueduct). Source: ArchivoTorroja-

CEHOPU.

\section{CONCLUSIONS}

This paper describes the important role of the Tempul Aqueduct in the history of bridge construction as a precursor of cable-stayed and extradosed bridges. This structure is also clear evidence of Torroja's audacity and courage in dealing with material uncertainty. In this work he carried out pioneering applications in prestressed concrete and developed new prestressing methods with the limited technology at his disposal.

In order to validate the innovative conceptual ideas and the actual response of the structure, Torroja's paper and pencil calculations were compared with different Finite Element Model (FEM) simulations. This comparison showed how the pylon height can be adjusted to ensure correct structural behavior in service. The FEMs also showed that the actual stay stiffness was lower than the one assumed by Torroja in his calculations. The time-dependent phenomena and the temperature effects were also evaluated; in the case of temperature, the results obtained are very close to the structure's actual behavior. The effect of placing hinges at the girder-pylon connection was also evaluated and the FEM simulations confirmed the improved structural behavior of a clamped connection, as Torroja himself had admitted. For that reason, the FEMs were also used to evaluate the behavior of the girder continuity. The role of the embedded stays in preventing the girder from lifting when the live loads are removed was evaluated conceptually and a numerical quantification of this effect should be addressed in future research.

Finally, the Tempul Aqueduct is also a clear example of the initial stages of a structural artist, as it fulfills the first two ideals of Structural Art, which are economy and efficiency. It also shows Torroja's potential for the third ideal, elegance, which were further developed in his subsequent work in which he achieved maturity as an engineer.

\section{ACKNOWLEGEMENTS}

Funding for this research has been provided to Mr Lozano-Galant by the Spanish Ministry of Economy, Industry and Competitiveness (Research Project BIA2013-47290-R from FEDER funds). The authors are also grateful to Prof. S. Buonopane of Bucknell University and J.L. Temprado, of COMPOSAN, for their assistance and support. The authors also want to thank the CEHOPU-Archivo Torroja, for all the information and support provided.

\section{REFERENCES}

1- Strasky, J. Stress ribbon and cable-supported pedestrian bridges, $2^{\text {nd }}$ Edition London: Thomas Telford, 2011.

2- FernándezTroyano, L. Bridge Engineering: A global perspective, Thomas Telford, 2003.

3- Podolny, W. and Scalzi, J.B. Construction and Design of Cable-Stayed Bridges, $2^{\text {nd }}$ Edition, New York: John Willey and Sons, 1986.

4- Billington D.P. and Nazmy, A. History and Aesthetics of Cable-stayed Bridges, Journal of Structural Engineering, 1988, 117(10): 3103-3134.

5- Buonopane, S. Billington, FESTSCHRIFT 2012, Essays in Honor of David P. Billington, A Historical Perspective on Suspension Bridges: Design VS Analysis and the Work of John A. Roebling, International Network for Structural Art, 2012. 
6- Manterola, J. Siegrist Fernández, C. and Gil Ginés, M.A, Puentes: Tomo VI, Escuela Técnica Superior de Ingenieros de Caminos, Canales y Puertos de Madrid, Madrid, 2006 [In Spanish].

7- Gimsing, N.J. and Georgakis, C.T.Cable-supported bridges-Concept and Design, $3^{\text {rd }}$ Edition, Chichester: John Willey and Sons, 2012.

8- Gimsing, N. J. History of Cable-Stayed Bridges, Proceedings IABSE Conference: Cable-Stayed Bridges- Past, Present and Future, Malmö, Sweden, 2-4 June, 1999.

9- Walther R. Houriet, B. Isler, W. Moia, P. Klein, J.F. Cable-stayed bridges, $2^{\text {nd }}$ Edition, Thomas Telford, 1999.

10- Virlogeux, M. Recent evolution of cable-stayed bridges, Engineering Structures, 1999, 21(8): 67-97.

11- Arenas de Pablo, J.J. Los puentes en España a lo largo del siglo XX, Revista de Obras Públicas 1999, 3388: 177-184, [In Spanish].

12- Myerscough, M. Suspension bridges, past and present, The Structural Engineer, 2013, 91(7): 1221.

13- Buonopane, S. The Technical Writings of John A. Roebling and his Contributions to Suspension Bridge Design. John A. Roebling, A Bicentennial Celebration of his Birth 1806-2006 Symposium, October $27^{\text {th }}$, Brooklyn, New York, 2006a.

14- Buonopane, S. The Roeblings and the Stayed Suspension Bridge: Its development and Propagation in the Nineteenth-Century United States, Proceedings of the Second International Congress on Construction History, $29^{\text {th }}$ March $4^{\text {th }}$ April $2006 \mathrm{~b}$.

15- Buonopane, S.and Brown, M.M. History and Engineering Analysis of the 1890 cable-stayed Bluff Dale Bridge,Proceedings of the First International Congress on Construction History, March $20^{\text {th }}-24^{\text {th }}$ January 2003.

16- Billington DP. The tower and the bridge: the new art of structural engineering.Princeton (USA): Princeton UniversityPress; 1985.

17- Jordá C, editor. Eduardo Torroja, la vigencia de un legado. Eduardo Torroja, the validity of a legacy. Valencia (Spain): Universidad Politécnica de Valencia; 2002 [In Spanish].

18- Fernández-Ordóñez JA, Navarro-Vera JR. Eduardo Torroja Ingeniero-Engineer. Pronaos, Madrid, Spain, 1999. Bilingual edition in Spanish-English.

19- Moragues JJ, Paya-Zaforteza I, Medina O, Adam JM. Eduardo Torroja's Zarzuela Racecoursegrandstand: Design, construction, evolution and criticalassessment from the Structural Art perspective. Engineering Structures, 2015, 105: 186-196.

20- Lozano-Galant, J.A. and Payá-Zaforteza, I.J. Structural analysis of Eduardo Torroja'sFrontón de Recoletos' roof, Engineering Structures, 2011, 33: 843-854.

21- Oliver M., Buitrago M., Paya-Zaforteza I., Adam JM. Eduardo Torroja's CASA Factory roof: an unbuilt Structural Art masterpiece. Engineering Structures 2016, 128:82-95.

22- Nuñez-Collado, G. Garzón-Roca, J. Paya-Zaforteza, I. Adam, J.M. The San Nicolas Church in Gandia (Spain) or how Eduardo Torroja devised a new, innovative and sustainable structural system for long-span roofs, Engineering Structures 56, 2013: 1893-1904.

23- Torroja, E. Memoria de Cálculo del Acueducto de Tempul, Original Document, 1927. [In Spanish].

24- Torroja Cavanillas, J.A. Eduardo Torroja, Ingeniería y Territorio, Revista del Colegio de Ingenieros de Caminos, Canales y Puertos, 2007,79: 98-103. [In Spanish].

25- Cabello A, Paya-Zaforteza I, Adam JM. Non-linearanalysis of Eduardo Torroja'sFrontón de Recoletos' roof using a discretereinforcementapproach. Engineering Structures; 2014, 80: 406417.

26- Thrall AP, Bréa KL, Billington DP. The Maria Pia Bridge: a major work of structural art. Eng Struct 2012, 40: 479-486.

27- Cresciania M, Forth J. Threeresilientmegastructures by Pier Luigi Nervi. Int J ArchitHeritage: Conserv, Anal Restor 2014, 8(1):49-73.

28- Garlock MEM, Billington DP. Félix Candela: engineer, builder, structural artist. New Haven: Yale UniversityPress; 2008.

29- Burger N, Billington DP. Felix Candela, elegance and endurance: an examination of the Xochimilco shell. J Int Assoc Shell Spatial Struct, 2006, 152: 271-278.

30- Thrall AP, Billington DP. Bayonne Bridge: the work of OthmarAmmann, master builder. $J$ Bridge Eng 2008, 13: 635-643.

31- Adriaenssens S, Brown N, Lowinger R, Hernandez J. Structural analysis of reinforcedconcretefoldedhyperbolicparaboloid: a case study of the modern mimai marine stadium. Int J ArchitHeritage: Conserv, Anal Restor2014, 8(4): 498-516. 
32- Torroja E. The structures of Eduardo Torroja; an autobiography of engineering accomplishment. New York: Dodge Corporation, USA; 1958.

33- Torroja E. Philosophy of structures. Berkeley, USA: University of California Press, 1958.

34- Torroja, E. Acueducto-Sifón sobre el río Guadalate, Revista de Obras Públicas, 2.477,1927. [In Spanish].

35- Ministerio de Fomento, 2007, Rehabilitation Works of the San Patricio Bridge. http://www.fomento.gob.es/mfom.cultural.web/detalleProyecto.aspx? $=01369$ Consulted on $02 / 12 / 2016$.

36- Lozano-Galant, J.A. Payá-Zaforteza, I.J. Dong. X. and Turmo, J. New Algorithm to model the construction process of cable-stayed bridges built on temporary supports. EngineeringStructures, 2012, 40: 119-130.

37- Preservation Texas, 2017, Preservation of Bluff Dale Bridge http://www.preservationtexas.org/endangered/bluff-dale-bridge/. Consulted on 08/05/2017.

38- The Flash Today, Current state of the Bluff Dale Bridge http://theflashtoday.com/2015/04/29/bluff-dales-historic-cable-stay-bridge-is-slipping-away/. Consulted on $08 / 05 / 2017$.

39- COWI, Bridge Operation and Maintenance http://www.cowiuk.com/topmenu/Documents/Bridge_Operation_Maintenance.pdf. Consulted on 08/05/2017.

40- Chen, S.G, Maintenance of cable-stayed bridges, PhD Thesis, National Taiwan University, 2000.

41- Mathivat, J. Recent developments in Prestressed concrete bridges, FIP Notes, 1988, 2: 15-2.

42- Benjumea, J. Chio, G. Maldonado, E. Structural behavior and design criteria of extradosed bridges: general insight and state of the art, RevistaIngeniería de Construcción, 2010, 25(3): 383-398.

43- Chio, G. Comportamiento Estructural y Criterios de Diseño de los Puentes con Pretensado Extradosados. Tesis Doctoral. Barcelona, Universidad Politécnica de Catalunya, 2000. [In Spanish].

44- Dos Santos, D. (2006) Comportamiento Estructural de Pontes Com Prentensao no Extradorso, Tesis de Mestrado, Sao Paulo: Escola Politécnica da Universidade de Sao Paulo. 2006, [In Portuguese].

45- Billington, D. Historical Perspective on Prestressed Concrete, PCI JOURNAL, 1996: 14-30.

46- Torroja Cavanillas JA, Eduardo Torroja. Personal Impressions in Eduardo Torroja: Obras y Proyectos. Instituto Eduardo Torroja. 2005.

47- Corres-Peiretti H., Romo J. and León J. Conceptual design inStructural Concrete, Textbook on behavior, design and performance, Second Edition, Volume 1. International Federation for StucturalConcrete (fib). 2009.

48- Lozano-Galant, J.A. Ruiz-Ripoll, L. Paya-Zaforteza, I. and Turmo, J. Modifications of the Stress-State of Cable-Stayed Bridges due to Staggered Constructions of their Superstructure, The Baltic Journal of Road and Bridge Engineering, 2014, 9(4): 241-250.

49- Lozano-Galant, J.A. Paya-Zaforteza, I. and Turmo, J. Effects in service of the staggered construction of cable-stayed bridges built on temporary supports, The Baltic Journal of Road and Bridge Engineering, 2015, 10(3): 247-254.

50- Jorquera-Lucerga, J.J., Lozano-Galant, J.A. and Turmo, J. Structural behavior of nonsymmetrical cable-stayed bridges, Steel and Composite Structures, 2016, 20(2), 447-468.

51- Janjic D, Pircher M, Pircher H. Optimization of cable tensioning in cable-stayed bridges. $J$ Bridge Eng2003, 131-7.

52- Lozano-Galant, J.A. and Turmo, J. An algorithm for simulation of concrete cable-stayed bridges built on temporary supports and considering time dependent effects, Engineering Structures, 2014,79(11): 341-353.

53- Lozano-Galant, J.A. Payá-Zaforteza, I.J. Dong. X. and Turmo, J. Analysis of the construction process of cable-stayed bridges built on temporary supports. Engineering Structures, 2012a, 40: 95-106.

54- Lozano-Galant, J.A. Dong. X. Payá-Zaforteza, I. and Turmo, J. Direct simulation of the tensioning process of cable-stayed bridges. Computers \& Structures, 2013, 121: 64-75.

55- Sap2000, 2015 "CSI Analysis Reference Manual for Sap2000, ETABS, Safe and CSi Bridge”, Berkeley, USA.

56- CEB-FIP Model Code 90, CEB Bulletin No. 213/214, 1993.

57- Haubans SETRA. Recommandations de la Commission Interministérielle de la Précontrainte, Service d'Etudes Techniques des Routes et Autoroutes, France; 2001. 


\begin{tabular}{|c|c|c|c|c|c|}
\hline Year & Name & References & Span (m) & Staysystem & Notes \\
\hline $1600 \mathrm{~s}$ & Pont Ferreus & [2] & -- & (A) & Heavy pylons instead of backstays \\
\hline $1700 \mathrm{~s}$ & Ponte Dell'Arsenalle & [2] & -- & (Q) & Drawbridge. \\
\hline 1784 & Leocher'sdesign & [2], [3], [9] & 32 & (B) & Timber bridge designed by a carpenter \\
\hline 1817 & King's-Meadows Footbridge & [2], [9] & 33 & (B) & Demolished in the $50 \mathrm{~s}$. \\
\hline 1817 & Dryburgh Bridge & [2], [3], [9] & 79 & (C) & Collapsed due to wind vibrations \\
\hline 1821 & Poyet-type Bridge & [3] & -- & (D) & Designed by architect Poyet \\
\hline 1821 & Brighton Chain Pier Bridge & [12], [13] & 308 & (E) & Stays to stiffen the girder, wind collapse \\
\hline 1823 & Menai Straits proposal & [4] & -- & (F) & Proposed by T. Telford with stays only in the backspan \\
\hline 1824 & River Saale Bridge & [2], [3], [9] & 78 & (G) & Collapsed due to overweight \\
\hline 1837 & Tiverton Bridge & [2] & -- & (G) & Vertical hangers from stay cables. \\
\hline 1840 & Gischlard-Arnodin Bridge & [3] & -- & (H) & Two stay systems with masonry pylons \\
\hline 1840 & Hatleychain Bridge & [3] & -- & (G) & Chain stays in a parallel configuration \\
\hline 1846 & Monongahela. Bridge & {$[5],[13]$} & 459 & (I) & Stay cables were used to stiffen the structure. \\
\hline 1850 & Lewiston-Queenston Bridge & [13] & 306 & (J) & Stay cables were used to stiffen the structure. \\
\hline 1855 & Niagara Falls Bridge & [2], [3], [5], [9], [13] & 250 & $(\mathrm{~K})$ & Stay cables were used to stiffen the structure. \\
\hline 1860 & Allegheny Bridge & [5] & -- & $(\mathrm{K})$ & Stay cables were used to stiffen the structure. \\
\hline 1867 & Cincinnati Bridge & [5], [13] & 322 & (J) & Stay cables were used to stiffen the structure. \\
\hline 1868 & Franz Joseph Bridge & [2] & 146 & (L) & In the proximities of the pylon hangers do not hang the girder \\
\hline 1868 & Rock Island Bridge & [14] & 168 & (J) & Stay cables were used to stiffen the structure. \\
\hline 1868 & East Rockport Bridge & [14] & 168 & (J) & Stay cables were used to stiffen the structure. \\
\hline 1869 & Union Bridge & [14] & 229 & (J) & Stay system counterbalances $45 \%$ of the loads \\
\hline 1869 & Lowelville Bridge & [14] & 145 & (J) & Stay system counterbalances $35 \%$ of the loads \\
\hline 1870 & Waco Bridge & [14] & 189 & (J) & Guys for storm protection \\
\hline 1871 & Newcastle Bridge & [2] & 73 & (M) & Rigid bar as stay cable. \\
\hline 1871 & Jones Mill Bridge & [14] & 92 & (J) & Stay system counterbalances $16 \%$ of the loads \\
\hline 1872 & Albert Bridge & [3], [9] & 122 & (J) & Girder stiffness enables notable stay separation \\
\hline 1879 & Saint-Ilpize Bridge & [2] & 68 & $(\mathrm{~N})$ & Arnodin's design \\
\hline 1883 & Lamothe Bridge & [2] & 115 & (O) & Arnodin's design \\
\hline 1883 & Brooklyn Bridge & {$[2],[3],[5],[7],[9]$} & 483 & (J) & Stayed system to reduce deformability \\
\hline 1888 & Midi Bridge & [2] & 127 & $(\mathrm{~N})$ & Arnodin's design \\
\hline 1890 & Barton Creek Bridge & [15] & -- & (P) & Patented prestressing twisting device \\
\hline 1899 & Bridge of Cassagne & [9] & 156 & (H) & Development of economic and rigid hangers \\
\hline 1899 & Bluff Dale Bridge & [15] & 43 & (P) & Patented prestressing twisting device \\
\hline 1900 & Aramon Bridge & [2] & 274 & (J) & Arnodin's design \\
\hline 1903 & Leamington Spa Footbridge & [2] & 30 & (R) & Gisclard's design \\
\hline 1904 & Bonhome Bridge & [2] & 163 & $(\mathrm{~N})$ & Arnodin's design \\
\hline 1911 & Tres-Cases Bridge & [2] & --- & (S) & Horizontal cables to avoid axial forces in girder. \\
\hline 1924 & Lazardrieux & [2], [9] & 112 & (T) & Girder compression to counterbalance horizontal forces. \\
\hline
\end{tabular}




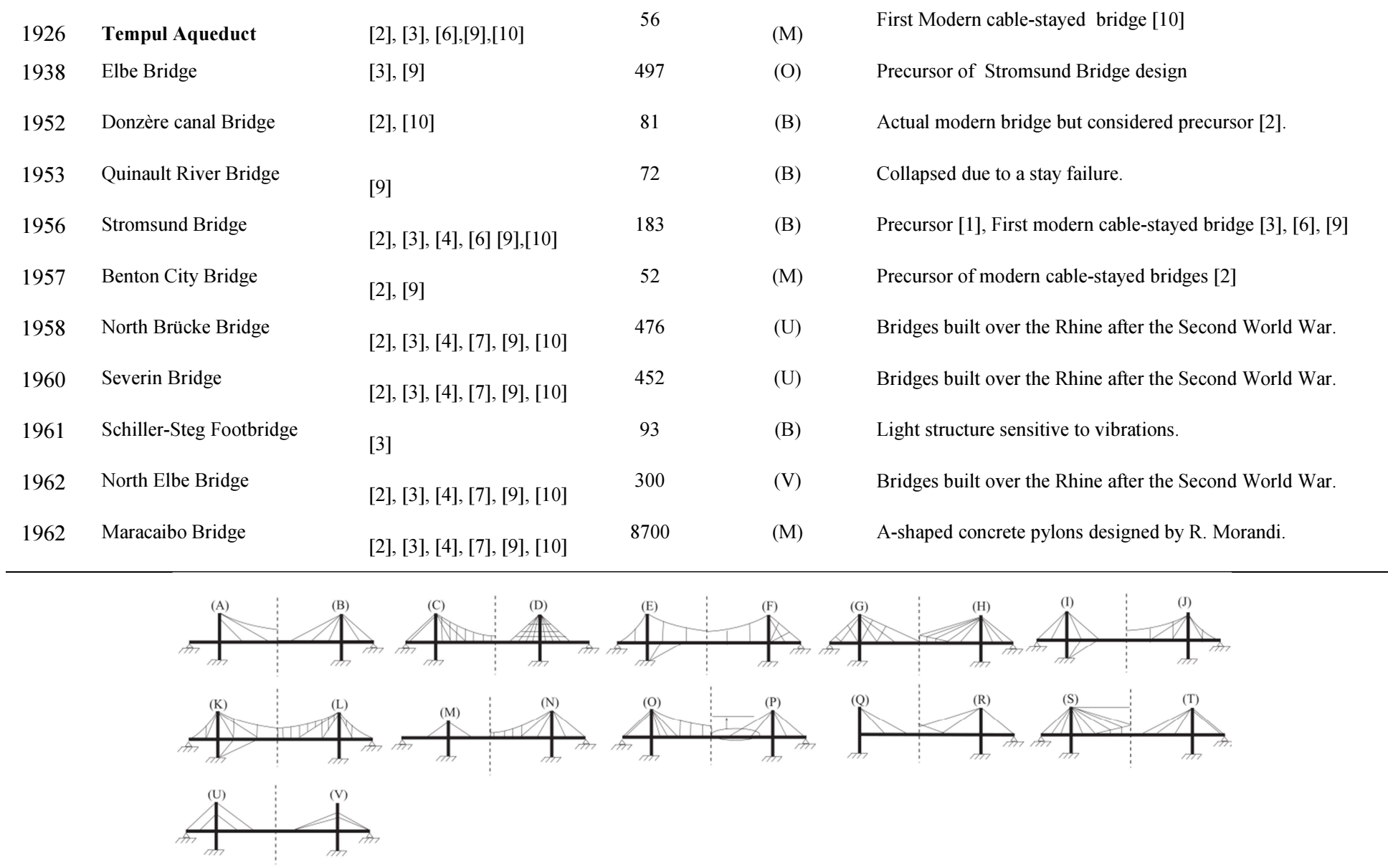

Table 1: Evolution of cable-supported bridges. 